\title{
Respective roles of remote and local wind stress forcings in the development of warm SST errors in the South-Eastern Tropical Atlantic in a coupled high-resolution model
}

\author{
Katerina Goubanova ${ }^{1,2} \cdot$ Emilia Sanchez-Gomez ${ }^{1} \cdot$ Claudia Frauen $^{3,4} \cdot$ Aurore Voldoire $^{3}$
}

Received: 13 December 2017 / Accepted: 31 March 2018 / Published online: 10 April 2018

(c) The Author(s) 2018

\begin{abstract}
Processes involved in the development of the warm sea surface temperature (SST) bias in the Tropical South-Eastern Atlantic (SETA) in a high resolution (HR) version of the CNRM-CM model are evaluated based on full-field initialized seasonal hindcasts starting at 1 February of each year for 2000-2009. Whereas the initial SST growth is likely associated with local atmospheric forcing, its further development is due to remote oceanic processes. A mixed layer heat budget analysis in SETA indicates a spurious warm horizontal advection observed as far as south of $25^{\circ} \mathrm{S}$ that appears at the beginning of March. It is associated with an erroneous oceanic mean state at the equator resulting from the mean equatorial westerly wind bias. A sensitivity experiment with corrected wind stress over the equatorial region suggests that the remote forcing explains about $57 \%$ of the SETA SST bias in March-May. Comparison with a lower resolution (LR) version of the model reveals that in general similar processes are responsible for the SST bias in both models. A strong reduction of the bias in the HR model is observed only over the near-coastal Southern Benguela region due to a better representation of atmospheric and oceanic processes controlling the coastal upwelling. Overall, the results of the inter-comparison of the SETA SST bias evolution in different sensitivity experiments performed in this study can be interpreted in terms of the relative contributions of (erroneous) warm horizontal advection, associated with equatorial forcing, and cold horizontal advection, associated with local offshore Ekman transport.
\end{abstract}

Keywords General circulation models · Model systematic biases · Atmosphere-Ocean coupling · Tropical Atlantic · Seasonal prediction $\cdot$ Benguela upwelling system

\section{Introduction}

The warm sea surface temperature (SST) bias in the SouthEastern Tropical Atlantic (SETA) is one of the major long standing problems for coupled general circulation models (CGCMs) that compromises seasonal to decadal predictions and climate change projections at regional and global scales

Katerina Goubanova

katerina.goubanova@ceaza.cl

CECI-CERFACS/CNRS, Toulouse, France

2 Centro de Estudios Avanzados en Zonas Áridas (CEAZA), La Serena, Chile

3 CNRM (Météo-France/CNRS), UMR 3589, Toulouse, France

4 Leibniz Institute for Baltic Sea Research Warnemünde, Rostock, Germany
(Davey et al. 2002). A large number of studies have focused on elucidating the causes of too warm SSTs in single models and multi-model ensembles [such as Coupled Model Intercomparison Project (CMIP) datasets], and found that a wide spectrum of local and remote errors in both oceanic and atmospheric components may contribute to the SST bias (Zuidema et al. 2016, and the references therein).

Among the main local atmospheric causes of the SETA SST biases are the well-known error in solar radiation associated with an underestimated stratocumulus cloud deck (Giese and Carton 1994; Stockdale et al. 1994; Ma et al. 1996; Richter and Mechoso 2006), and the error in evaporative cooling associated with an overestimated near-surface relative humidity, the latter being demonstrated by Hourdin et al. (2015). These errors, originating primarily from deficiencies in the atmospheric model physics, are strongly involved in ocean-atmosphere feedback processes which 
may amplify or, on the contrary, partially hide the SST biases (Wahl et al. 2011; Xu et al. 2014a).

Another local cause of the bias is associated with poor representation of the coastal upwelling and is generally attributed to a too-coarse resolution of both oceanic (Grodsky et al. 2012) and atmospheric (Cambon et al. 2013; Machu et al. 2015; Small et al. 2015; Milinski et al. 2016) components of CGCMs. The intensity of the wind-driven coastal upwelling in the SETA is dynamically linked to the strength of the equatorward Benguela current. The Benguela current causes equatorward advection of cool water along the coast from the southern tip of Africa to about $16^{\circ} \mathrm{S}$, where it meets the warm southward-flowing Angola Current (e.g. Shannon et al. 1987). Grodsky et al. (2012) suggest that insufficient horizontal oceanic resolution in the models leads to an insufficient northward transport of cool water along the coast. This results in an overshooting of the Angola current over the Angola-Benguela Frontal Zone (ABFZ), which contributes to the local SST bias through horizontal heat transport. Small et al. (2015) argue that errors in wind stress curl in too coarse resolution atmospheric models can lead to unrealistic vertical velocities and southward flow along the coast extending too far south. They further suggest that an oceanic eddy-resolving resolution along with an atmospheric resolution of at least $0.5^{\circ}$ are required to realistically simulate the equatorward coastal current (cold advection) and strong upwelling localized at the coast. Besides the model resolution issue, a weaker than observed upwelling, and thus the warm SST bias, can also be due to underestimated alongshore winds related to biases in intensity (and position) of the subtropical anticyclone (Richter et al. 2012; Cabos et al. 2017). Koseki et al (2017) recently demonstrated that an overshooting of the Angola current can be associated not only with a too weak wind-driven upwelling in the Benguela region, but also with a local cyclonic surface wind error over the ABFZ that drives an excessively strong Angola Current.

Along with the local factors, the warm SST biases in the SETA also seem to be systematically associated with remote forcing (Toniazzo and Woolnough 2014; Xu et al. 2014a). Indeed, well-documented westerly wind biases simulated by the global circulation models in the equatorial Atlantic in March-April-May (MAM) lead to an erroneous ocean mean state characterized by a reversed thermocline east-west gradient (Xu et al. 2014a). Deepening of the thermocline in the eastern equatorial Atlantic prevents the development of the cold tongue in boreal summer and results in a strong regional warm SST error along the equator. Furthermore, numerical experiments, in which the model surface winds were replaced with observed winds over the equatorial region, showed that the subsurface temperature bias in the equatorial thermocline is transported to the coastal region south of the ABFZ (Richter et al. 2012; Wahl et al. 2011; Voldoire et al. 2014) and, depending on the model, may contribute up to $25 \%$ to the local SST bias (Richter 2015). Two main mechanisms are used in literature to explain this oceanic teleconnection: mean horizontal advection and Kelvin waves propagating along the equator and then along the western coast of southern Africa (e.g. Xu et al. 2014b). However, it has not been elucidated yet which of these processes is dominant and/or how they are linked together in terms of impact on the SETA SST errors. Another question that can arise in this regard is whether the local response to the remote error depends on the regional mean state in the SETA region and, in particular, whether the realistic representation of the coastal upwelling associated with a sufficiently strong Benguela current can disable the propagation of warm anomalies from the equator to the South-Eastern Atlantic.

In this study we examine the causes of the SETA warm SST bias in a high-resolution (HR) version of the CNRMCM CGCM (Monerie et al. 2017) with a particular focus on the role of remote forcing from the equator. Given the difficulty to identify the primary sources of the models' biases based on standard CMIP-type control or historical simulations, in which coupled and remotely teleconnected errors are fully developed, we performed model integrations in seasonal hindcast mode from well-defined full-field initial conditions derived from observations. The relevance of this approach for examining the sequence of the mechanisms involved in the development of the model systematic errors in the Tropics has been shown by Huang et al. (2007), Toniazzo and Woolnough (2014) and Shonk et al. (2016). Our hindcast integrations start in February each year and last 6 months, which allows tracing the initial rapid development of the SST bias and its further evolution during MAM and June-July, the seasons corresponding to the strongest equatorial westerly wind bias and to the strongest SST bias in the equatorial cold tongue region, respectively (Fig. 1). In order to quantify the impact of the local and remote wind errors in setting up the SST bias in the SETA region we follow the approach of Voldoire et al. (2014), and carry out partially coupled sensitivity experiments in full-initialized seasonal hindcast mode. Given that the basis of this study is a highresolution model, we are naturally interested in evaluating whether and to what extent the high resolution can improve the SETA bias. To do this, control hindcast integrations were also performed with a lower resolution (LR) version of the CNRM CGCM.

This work is part of the coordinated effort undertaken within the PREFACE project (Enhancing prediction of Tropical Atlantic climate and its impacts, http://preface.b.uib. no/) with a primary aim of identifying common causes of SETA biases across different CGCMs. The paper is structured as follows. The next section describes the model, experiments performed and methods. In Sect. 3 we analyze the link between the SETA SST bias and the model errors in the surface wind at the equator. Section 4 examines the 

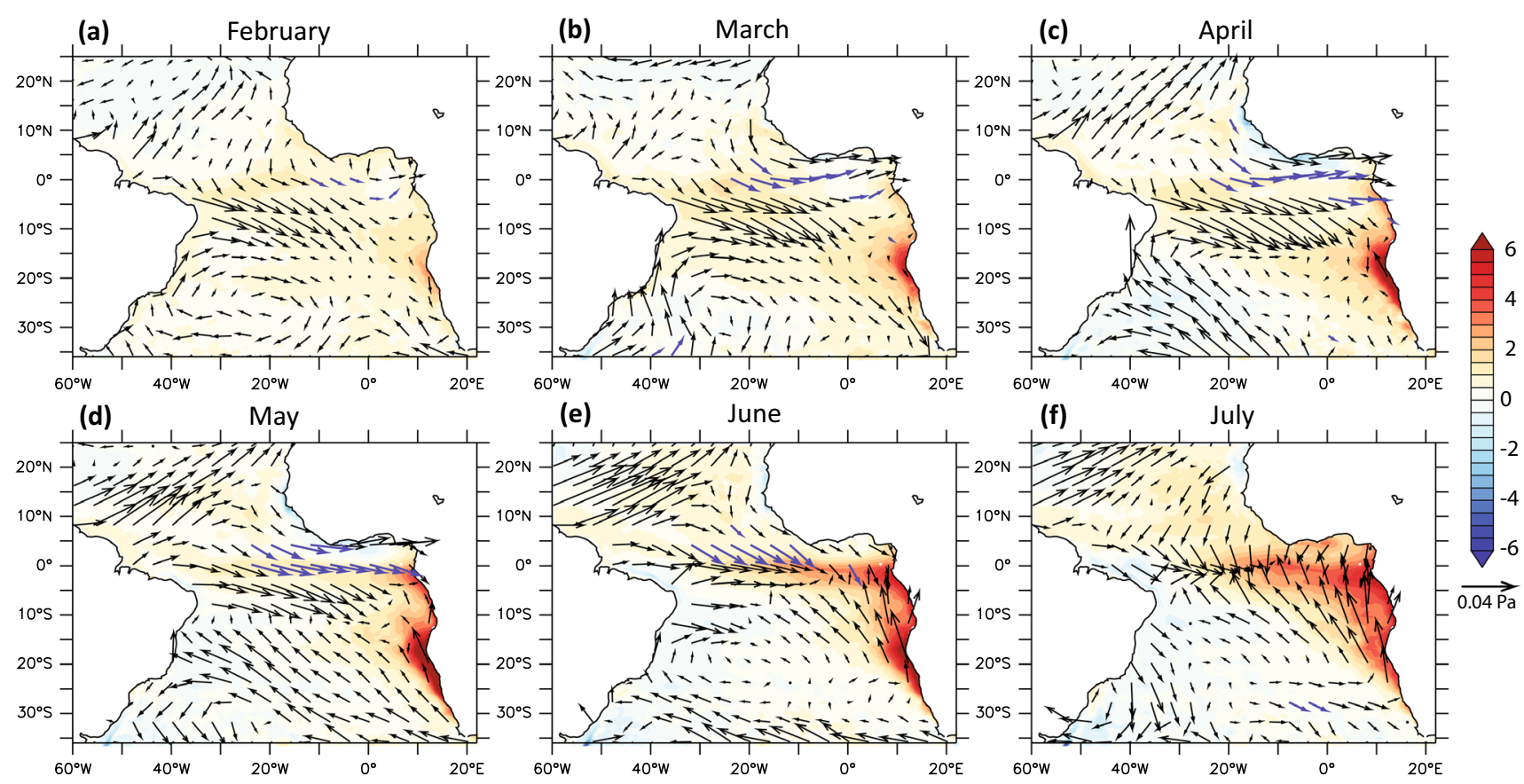

(e)
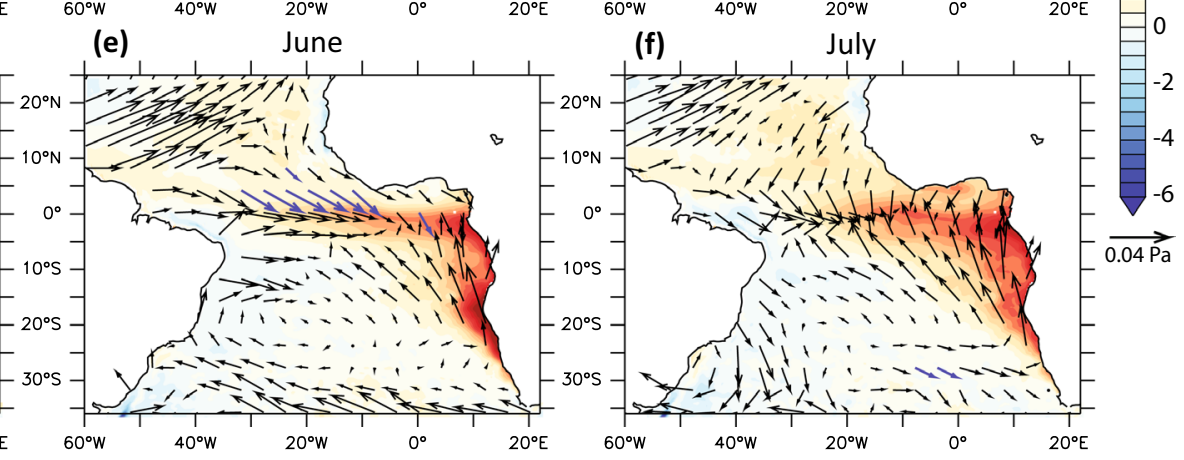

Fig. 1 Time-evolution of the monthly mean errors in SST (shading, ${ }^{\circ} \mathrm{C}$ ) and in wind stress (arrows, Pa) in CTRL-HR with respect to GLORYS2V3 and ERA-Interim, respectively. The blue arrows indi-

sensitivity of the SETA SST to local wind stress forcing. Section 5 is devoted to the evaluation of the added value of the high-resolution model used in this study against a lower resolution version of the model. This is followed by a discussion in Sect. 6 and concluding remarks in Sect. 7.

\section{Models, experimental design and methods}

\subsection{Models}

The high-resolution version of the CNRM-CM model used in this study was developed at the Centre Européen de Recherche Avancée en Calcul Scientifique (CERFACS) [cf. Monerie et al. (2017) for a brief description of the model]. It consists of the atmospheric model ARPEGE-Climat (v5.3) (Déqué et al. 1994) with the embedded land surface scheme ISBA (Noilhan and Planton 1989) and the oceanic model NEMO (v3.4) (Madec 2008) with the embedded sea ice model LIM2 (v3.3) (Vancoppenolle et al. 2009), coupled together through the OASIS3-MCT2.0 coupler (Valcke et al. 2013). The atmospheric component operates with a linear triangular truncation T359 corresponding to a gaussian grid of about $0.5^{\circ}$ horizontal resolution with 31 vertical levels and the oceanic component is discretized on an ORCA025L75 grid (horizontal resolution of about $0.25^{\circ}$ and 75 vertical levels, 18 levels being in the first $50 \mathrm{~m}$ ). This cate where the monthly mean zonal wind stress is easterly in ERAInterim but westerly in the model

resolution is considered as high for a CGCM (Haarsma et al. 2016) since it is significantly finer than the typical model resolutions used in CMIP5 (Taylor et al. 2012) $\left(1.5^{\circ}\right.$ and $1^{\circ}$ in the atmosphere and ocean, respectively). The lower resolution (LR) version of the CNRM-CM model used to evaluate the added value of the high resolution in simulating the SETA SST corresponds to the CMIP5 version (CNRMCM5.1, Voldoire et al. 2013). It includes the atmospheric component (ARPEGE-Climat, v5.2) on a T127 grid $\left(\sim 1.4^{\circ}\right)$ with 31 vertical levels and the oceanic component (NEMO, v3.2) on an ORCA1L42 grid $\left(\sim 1^{\circ}\right.$ of horizontal resolution and 42 vertical levels, 5 levels being in the first $50 \mathrm{~m}$ ). The ocean-atmosphere coupling time steps in the HR and LR versions are $3 \mathrm{~h}$ and 1 day, respectively. Additional sensitivity tests performed with the HR model indicated that the magnitude and evolution of the SST bias in the 6-months long hindcasts starting in February are similar for $3 \mathrm{~h}$ and 1 day coupling in both SETA and equatorial Atlantic region (not shown).

It is important to note that the atmospheric components of the HR and LR models share exactly the same physical parametrizations and corresponding parameters tuning (the differences between v5.3 and v5.2 of ARPEGE, used in the HR and LR models respectively, concern only bug fixes). On the other hand, the differences between the v3.4 and v3.2 of NEMO include some improvements in the physics and numerical schemes. At the air-sea interface the HR model uses the Louis's (1979) formulations for a direct 
computation of the exchange coefficients for the air-sea turbulent fluxes, whereas in the LR model the respective calculations are based on the Exchange Coefficients from Unified Multi-Campaigns Estimates (ECUME, Belamari 2005).

Among other, rather small differences, between two versions, it should be mentioned different treatments of air-sea coupling at the coastal grid cells containing part ocean and part land. Both versions of the model use the same land surface scheme ISBA. However, in the LR version ISBA is externalized through the use of the SURFface EXternalisee (SURFEX) modeling platform developed at Météo-France. The representation of the surface in SURFEX is based on the concept of "tiles" (natural land surface, urbanized areas, lakes and oceans), which allows sending to the near-coastal oceanic grid cells the surface fluxes calculated only over the ocean part of the corresponding atmospheric grid cells. In contrast, in the HR model, although the near-coastal oceanic grid cells receive the surface fluxes only from the atmospheric grid cells assigned as ocean (i.e. containing generally less than $20 \%$ of the land fraction), the respective fluxes in each of these atmospheric cells are "contaminated" by land since they represent the average of the fluxes calculated over the ocean part and over the land part weighted by their respective fractions. Note that the near-coastal oceanic wind sent to the ocean in the LR model is "contaminated" by land in the same manner as the surface fluxes in the HR model, because there is no tiling in the boundary layer.

Other minor (relative to the focus of the present study) differences between the HR and LR models consist in using of different sea-ice models (GELATO v5 (Salas-Mélia 2002) for the LR version) and in using a river routing model [TRIP, Oki and Sud (1998)] in the LR version in contrast to the HR version that uses a climatological river transport to the ocean.

\subsection{Experiments description}

Table 1 provides a summary of the seasonal hindcast integrations considered in this study. All integrations cover the period 2000-2009 and consist of ten 6-months long,

Table 1 Description of the experiments

\begin{tabular}{ll}
\hline Experiment name & Description \\
\hline CTRL-HR & Control run with the HR model \\
CTRL-LR & Control run with the LR model \\
TAU-EQ & Wind stress prescribed over the \\
& Equatorial Atlantic from $5^{\circ} \mathrm{S}$ \\
& to $5^{\circ} \mathrm{N}$ (HR model) \\
TAU-SE & Wind stress prescribed locally \\
& over the SETA region: \\
& $30^{\circ} \mathrm{S}-10^{\circ} \mathrm{S}, 0^{\circ}$-coast (HR \\
& model) \\
\end{tabular}

three-member ensemble hindcasts. The hindcasts started each year on 1 February from the atmospheric and oceanic initial conditions provided by the ERA-Interim (Dee et al. 2011) and GLORYS2v3 (Ferry et al. 2010) reanalyses, respectively. The main reason for using GLORYS2v3 is that it is provided on the same high-resolution oceanic grid as the HR model, which avoids the remapping of the initial conditions on the model grid and associated spurious effects. GLORYS2v3 was produced with the NEMO (v2.1) global oceanic model forced by ERA-Interim corrected fluxes. The initial conditions for the different members of the HR hindcasts were created following Swingedouw et al. (2013): a white-noise perturbation with an anomaly chosen randomly for each grid point in the interval [ -0.05 , $\left.0.05{ }^{\circ} \mathrm{C}\right]$ was applied on the observed SST initial conditions. In the case of the LR hindcast the initial perturbation between the members was performed in the atmosphere using a random noise of amplitude 1/10 of the interannual variability simulated by the model (Guemas et al. 2016).

First, the control integrations, CTRL-HR and CTRLLR hereinafter, were performed in order to document the forming and evolution of the SETA SST bias in the HR and LR models, respectively. Then, with the aim of assessing the role of remote and local wind forcing in the development of the SETA SST bias in the HR model, we carried out two sensitivity experiments, TAU-EQ and TAU-SE. In these two experiments the ERA-Interim wind stress data from the forecast step 12 for 0 and $12 \mathrm{~h}$ were interpolated on the model coupling timestep (every $3 \mathrm{~h}$ ), and then prescribed to the oceanic component instead of the modeled wind stress over the Equatorial Atlantic $\left(5^{\circ} \mathrm{S}-5^{\circ} \mathrm{N}\right)$ and South-Eastern Atlantic $\left(30^{\circ} \mathrm{S}-10^{\circ} \mathrm{S}, 0^{\circ}\right.$-coast $)$, respectively. The remapping of the ERA-Interim fields on the ORCA025 spatial grid was done using a bicubic interpolation method, which allows conserving 2nd order property, in particular wind stress curl (Valcke 2013). Note, that similarly to the sensitivity experiments conducted by Wahl et al. (2011) and Richter et al. (2012), the modifications in wind stress impacted only momentum exchanges, whereas turbulent heat fluxes continued to be calculated based on the modeled near-surface winds. In order to avoid spurious effects due to sharp wind stress gradients between the modeled and ERA-Interim wind stress, the blending was performed according to: $\tau=(1-\alpha) \cdot \tau_{\bmod }+\alpha \cdot \tau_{\text {erai }}$, where $\tau_{\text {mod }}$ is the modeled wind-stress, $\tau_{\text {erai }}$ is the ERA-Interim wind-stress and $\alpha$ is the restoring coefficient. In the case of TAU-EQ, the value of $\alpha$ depends on the latitude and is 1 between $5^{\circ} \mathrm{S}$ and $5^{\circ} \mathrm{N}, 0$ poleward of $12^{\circ} \mathrm{N}$ and $12^{\circ} \mathrm{S}$, and follows a smooth step-like function in the $5^{\circ} \mathrm{S}-12^{\circ} \mathrm{S}$ and $5^{\circ} \mathrm{N}-12^{\circ} \mathrm{N}$ latitudinal bands, similarly to the restoring coefficient used in Ortega et al. (2017). In the case of TAU-SE the value of $\alpha$ depends on both, latitude and longitude, and follows a generalized Gaussian function (with 
the shape parameter of 8 , and scale parameters of $2 \times 10^{9}$ and $2.1 \times 10^{9} \mathrm{~km}$ in longitudinal and latitudinal directions, respectively) around $10^{\circ} \mathrm{W}, 20^{\circ} \mathrm{S}$.

The choice of the ERA-Interim wind stress rather than satellite products, in particular QuikSCAT, for the PREFACE coordinated experiments was mainly motivated by the fact that the reanalysis product guarantees the absence of spatial or temporal gaps and that it covers a relatively long period. Although the simulations analyzed in the present paper were limited to a 10-years period due to the high computational cost required by the HR model, the simulations with lower resolution models participating in the coordinated experiments extended to a 20 years period (1990-2009), which allowed gaining more statistical significance in the study of the systematic errors.

\subsection{Method}

Since we focus on the model systematic biases, in the following all diagnostics are provided for the ensemble means of a given hindcast integration. Reanalysis (or observational) data used to evaluate the biases are sampled and averaged accordingly. As our objective is to document the processes through which the model SETA SST starts to deviate from the initial conditions towards the fully developed coupled bias, the evolving SST error is calculated with respect to GLORYS2v3 utilized for the hindcast initialization. Note that GLORYS2v3 itself has a slight warm SST bias locally near the coast in the SETA region: about $0.35^{\circ} \mathrm{C}$ on average over 2000-2009 in a $4^{\circ}$-wide coastal band between $25^{\circ} \mathrm{S}$ and $15^{\circ} \mathrm{S}$ (not shown), with respect to the OISST dataset (Reynolds et al. 2002).

In order to analyze in detail the processes involved in the formation of the SETA warm bias the heat budget within the time varying upper-ocean mixed layer was computed online as follows:

$$
\begin{aligned}
\underbrace{\partial_{t}\langle T\rangle}_{\text {Total temperature tendency }}= & \underbrace{\frac{Q^{*}+Q_{s}-Q_{p}}{\rho_{0} C_{p} h}}_{\text {Atm. forcing }}-\underbrace{\langle U \cdot \nabla T\rangle}_{\text {Horiz. advection }}-\underbrace{\left\langle w \cdot \partial_{z} T\right\rangle}_{\text {Vert. advection }} \\
& -\underbrace{\frac{1}{h}\left(K_{z} \partial_{z} T\right)_{z=-h}}_{\text {Vert. mixing }}+\underbrace{\left\langle D_{l}(T)\right\rangle}_{\text {Lateral diffusion }}+\underbrace{\text { Res }}_{\text {Residual }},
\end{aligned}
$$

where $T$ is the model potential temperature; $h$ is mixed-layer depth calculated as the depth where the density differs by $0.01 \mathrm{~kg} \mathrm{~m}^{-3}$ from the $10 \mathrm{~m}$ depth density; $Q^{*}$ and $Q_{s}$ are the non-solar and solar components of air-sea heat fluxes, respectively, whereas $Q_{p}$ is the fraction of solar radiation that penetrates below the base of the mixed-layer depth; $U$ and $w$ are the horizontal and vertical velocities; $K_{z}$ is the vertical diffusion coefficient; $D_{l}(T)$ is the lateral diffusion and Res is the residual term. Brackets denote the vertical average over the mixed-layer depth: $\langle\cdot\rangle=\frac{1}{h} \int_{-h}^{0} \cdot d z$. The temperature tendency on the left side of Eq. (1) is thus controlled, from left to right, by air-sea heat flux storage in the mixed layer, horizontal and vertical advection, vertical mixing at the base of the mixed layer and lateral diffusion. In the following, the temperature tendency will be noted as TOT, the atmospheric forcing term as FORC, the horizontal advection as XY-ADV, the vertical advection as Z-ADV, and the vertical mixing as MIX. Note that the entrainment at the base of the mixedlayer is accounted for by the residual term (RES hereinafter), which also includes possible errors of the other terms. Each of the separate terms in Eq. (1) is computed by the ocean model and stored as a daily average. Lateral diffusion is found to only be a weak contributor to the mixed layer heat budget (not shown) and will not be discussed further.

The heat budget analysis of the upper-ocean mixed layer will be analyzed in three boxes: ATL $3\left(3^{\circ} \mathrm{S}-3^{\circ} \mathrm{N}, 20^{\circ} \mathrm{W}-0^{\circ}\right.$, corresponding to the cold tongue region), $\mathrm{ABA}\left(25^{\circ} \mathrm{S}-15^{\circ} \mathrm{S}\right.$, $4^{\circ}$-wide near-coastal fringe, corresponding to the AngolaBenguela area where the model bias is maximum) and $\operatorname{SBEN}\left(34^{\circ} \mathrm{S}-25^{\circ} \mathrm{S}, 2^{\circ}\right.$-wide near-coastal fringe, corresponding to the southern Benguela region characterized by coastal upwelling regime in both, observations and model) (Fig. 2). Note that our definition of the ABA box is based on the representation of the Angola-Benguela area in the CNRM CGCM and is different from the one used by Florenchie et al. (2004) and Lübbecke et al. (2010), who analyzed the SST interannual variability from observations (cf. Fig. 3 to compare the observed and simulated positions of ABFZ). When describing the mixed-layer heat budget we assume that the temperature is fairly uniform within the mixed layer and that the box-average evolutions of SST can be used as a proxy of the evolution of mixed layer averaged temperature.

\section{Link between SETA SST bias and errors at the equator}

\subsection{SST and subsurface temperature biases in CTRL-HR and TAU-EQ}

Figure 3 shows the evolution of the Atlantic SST error along the equator and along the African southwestern coast for the different experiments. For CTRL-HR (Fig. 3a) the error along the equator is rather weak until mid-May (in general less than $1^{\circ} \mathrm{C}$ ) but then it suddenly increases in the east to reach $4{ }^{\circ} \mathrm{C}$ in July. In the coastal region, between the equator and $12^{\circ} \mathrm{S}$, the error reaches its maximum also in June-July, but it grows almost linearly from February to June. In contrast, between $15^{\circ} \mathrm{S}$ and $34^{\circ} \mathrm{S}$ the error grows very quickly from the first days of the hindcast until the beginning of May and then it starts to decay. The strongest 


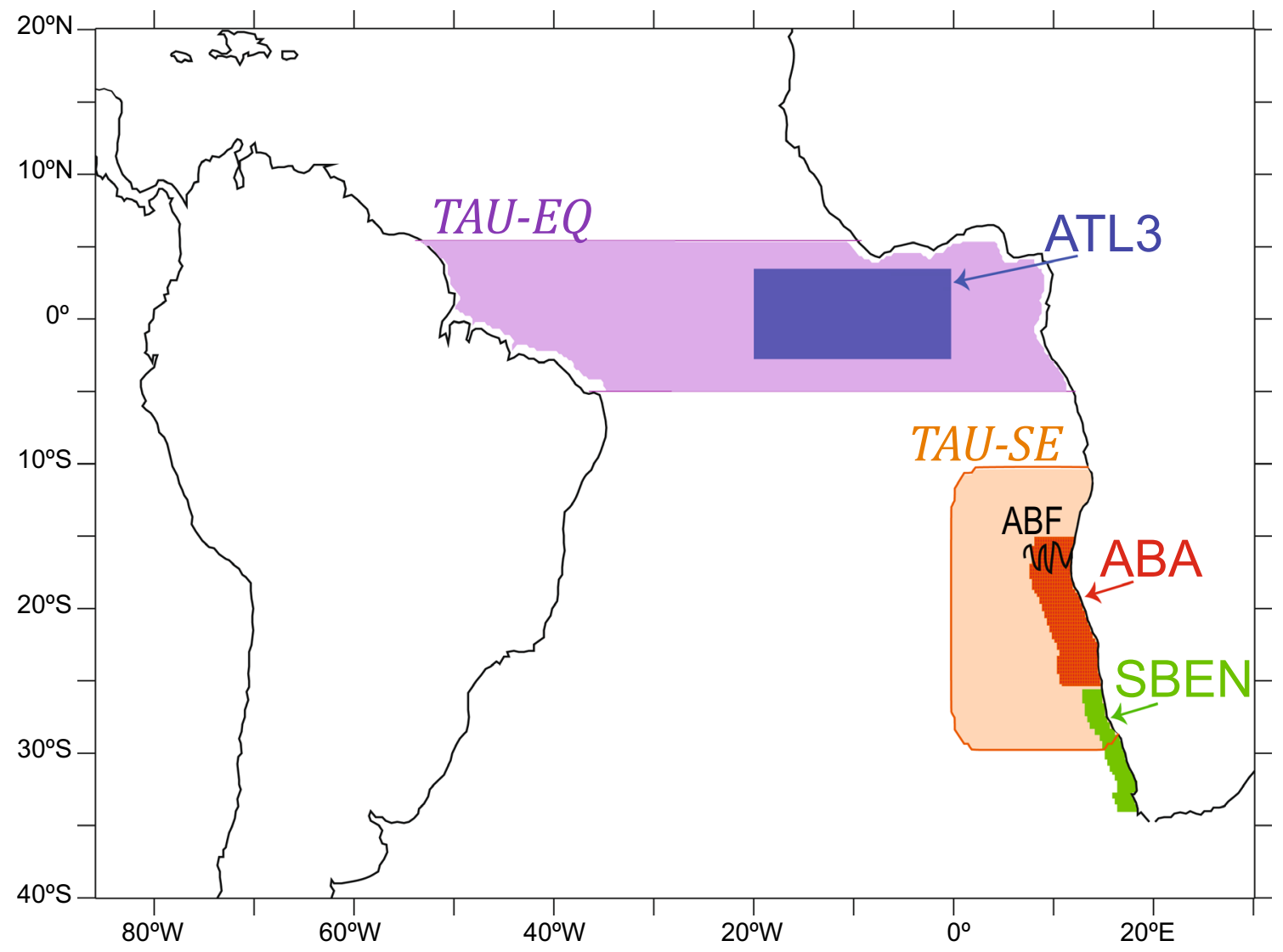

Fig. 2 Two regions in the Tropical Atlantic where the wind stress is prescribed in the sensitivity experiments: $T A U-E Q\left(5^{\circ} \mathrm{S}-5^{\circ} \mathrm{N}\right.$, purple) and $T A U-S E\left(0^{\circ}-\right.$ coast, $30^{\circ} \mathrm{S}-10^{\circ} \mathrm{S}$, orange). The three boxes used for the mixed layer heat budget analysis are also shown: Blue for ATL3 $\left(3^{\circ} \mathrm{S}-3^{\circ} \mathrm{N}, 20 \mathrm{~W}^{\circ}-0^{\circ}\right)$, red for $A B A\left(25^{\circ} \mathrm{S}-15^{\circ} \mathrm{S}, 4^{\circ}\right.$-wide strip off the

error occurs between $15^{\circ} \mathrm{S}$ and $20^{\circ} \mathrm{S}$ (more than $8^{\circ} \mathrm{C}$ at the end of April-beginning of May) and is associated with a southward shift of the Angola-Benguela Front (ABF).

The spatial pattern and timing of the surface bias shown in Fig. 3a may let one think that we deal with two different errors: one in the SETA region and the other one in the equatorial region. However, a look at subsurface layers lends a more comprehensive picture of what happens. Indeed, Fig. 4 demonstrates that the evolution of the error in subsurface temperature in the Tropical Atlantic is associated with a shallowing of the thermocline in the west and with its deepening in the east. Consequently, a strong anomalous warm signal appears approximately at the depth of the $20{ }^{\circ} \mathrm{C}$ isotherm (proxy for thermocline depth). Since the $20^{\circ} \mathrm{C}$ isotherm crops out between $20^{\circ} \mathrm{S}$ and $15^{\circ} \mathrm{S}$ along the coast, the SST bias is strongest in this region and appears much earlier than the SST bias at the equator. Thus, Fig. 4 suggests clearly that the equatorial and SETA regions share a common temperature bias. Flattening of the thermocline at the equator is also associated coast) and green for $\operatorname{SBEN}\left(34^{\circ} \mathrm{S}-25^{\circ} \mathrm{S}, 2^{\circ}\right.$-wide strip off the coast). A schematic representation of the observed mean position of the Angola-Benguela front (ABF) at $15-17^{\circ} \mathrm{S}$ (Veitch et al. 2006) is indicated in black

with a strong error in oceanic zonal circulation characterized in CTRL-HR by the absence of the westward South Equatorial Current, at least during the first 4 months of the hindcast, and by an eastward Equatorial Undercurrent that extends to the surface (not shown). This wrong equatorial ocean state is a result of the "classical" westerly wind bias of state-of-the-art CGCMs (Xu et al. 2014a) that is also found in our model (Fig. 1) and will be analyzed in details in the next section.

Indeed, prescribing the observed wind stress to the oceanic component of the model over the equatorial Atlantic between $5^{\circ} \mathrm{S}$ and $5^{\circ} \mathrm{N}$ in the experiment TAU-EQ, leads to a realistic simulation of the thermocline depth and to an almost total disappearance of the subsurface bias (Fig. 5). By consequence, there is a significant (by about 50\%) reduction of the SST bias at the equator and along the coast with a generally more realistic representation of the position of the ABF (Fig. 3b). The maximum bias, exceeding barely $4{ }^{\circ} \mathrm{C}$, is observed in the same region as in CTRL-HR but at the end of March instead of April-May. 

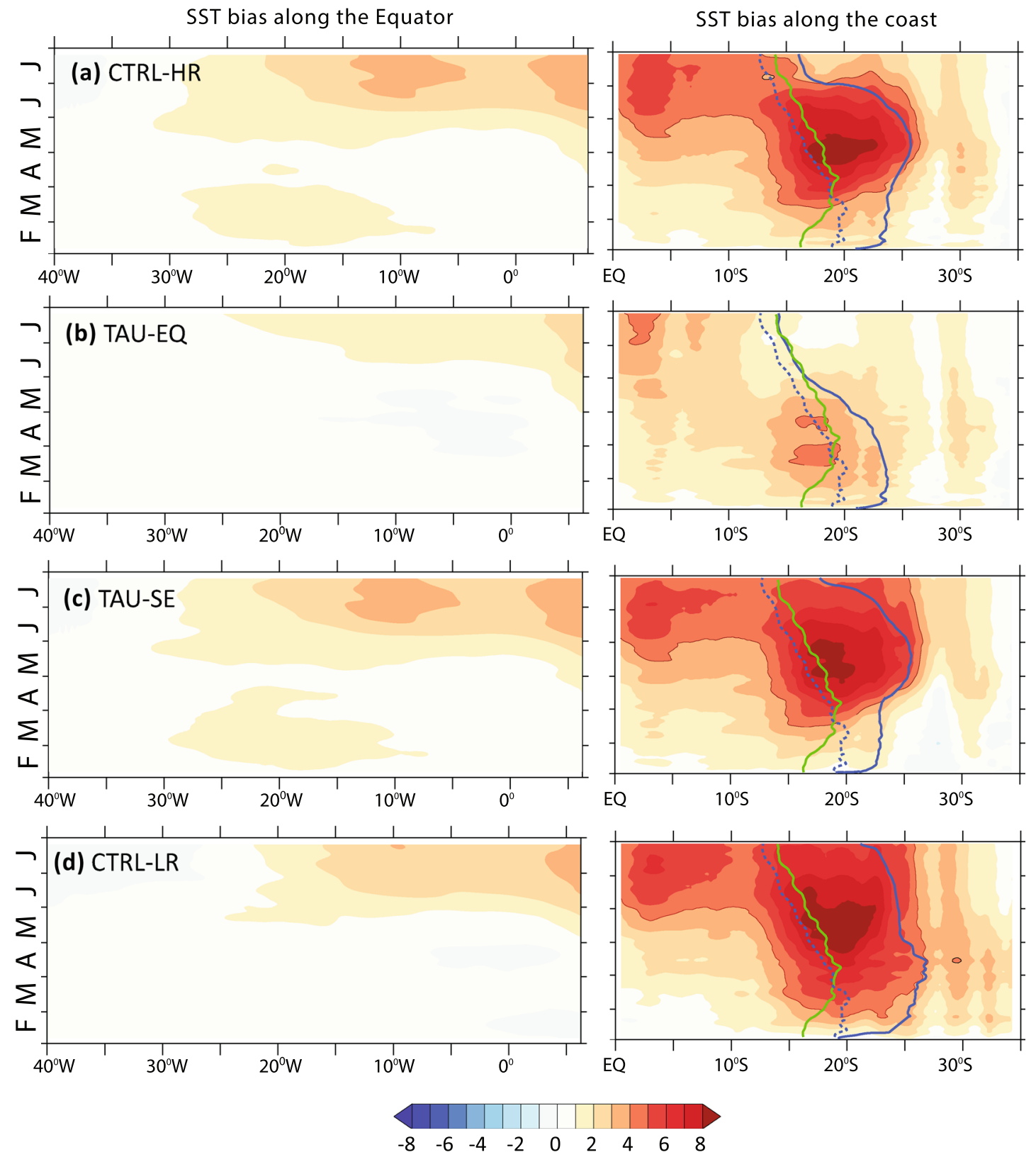

Fig. 3 Evolution of SST error (left) along the equator, averaged between $2^{\circ} \mathrm{S}-2^{\circ} \mathrm{N}$, and (right) along the south-western coast of Africa, averaged over $2^{\circ}$ wide strip off the coast, for (from top to bottom): CTRL-HR, TAU-EQ, TAU-SE and CTRL-LR. The bias is

\subsection{Improvement of the simulated SST at the equator in TAU-EQ and processes involved}

To determine which processes are relevant for the improvement of the simulated equatorial SST in TAU-EQ we compare the evolution of the tendency terms for the mixed layer heat budget in CTRL-HR and TAU-EQ over the equatorial ATL3 box. Firstly, Fig. 6 (left) shows the calculated with respect to GLORYS2V3. Blue plain, blue dashed and green plain contours indicate the $21{ }^{\circ} \mathrm{C}$ isotherm, which lies within the Angola-Benguela frontal zone, in the model, GLORYS2V3 and the OISST dataset, respectively. Unit: ${ }^{\circ} \mathrm{C}$

evolution of the mixed-layer temperature. The observations (red line) show an increase in SST from 28 to $29^{\circ} \mathrm{C}$ during the first 2 months of the hindcast and then, after almost no changes in April, a rapid seasonal cooling with SST decreasing by $4.5^{\circ} \mathrm{C}$ between May and July, corresponding to the development of the Atlantic cold tongue. In CTRLHR (black line) the SST increases from the beginning of the forecast until mid-March up to $29.7^{\circ} \mathrm{C}$, after which it 
Fig. 4 Time-evolution of the monthly-mean temperature error (left) along the equator, as a function of depth and degrees longitude, and (right) along the south-western coast of Africa, as a function of depth and degree latitude, in CTRL-HR. Along the equator the data are averaged within $2^{\circ} \mathrm{S}-2^{\circ} \mathrm{N}$ and along the coast the data are averaged within $2^{\circ}$ off the coast. The plain and dashed contours indicate the depth of the $20{ }^{\circ} \mathrm{C}$ isotherm in the model and GLORYS2V3, respectively. Unit: ${ }^{\circ} \mathrm{C}$
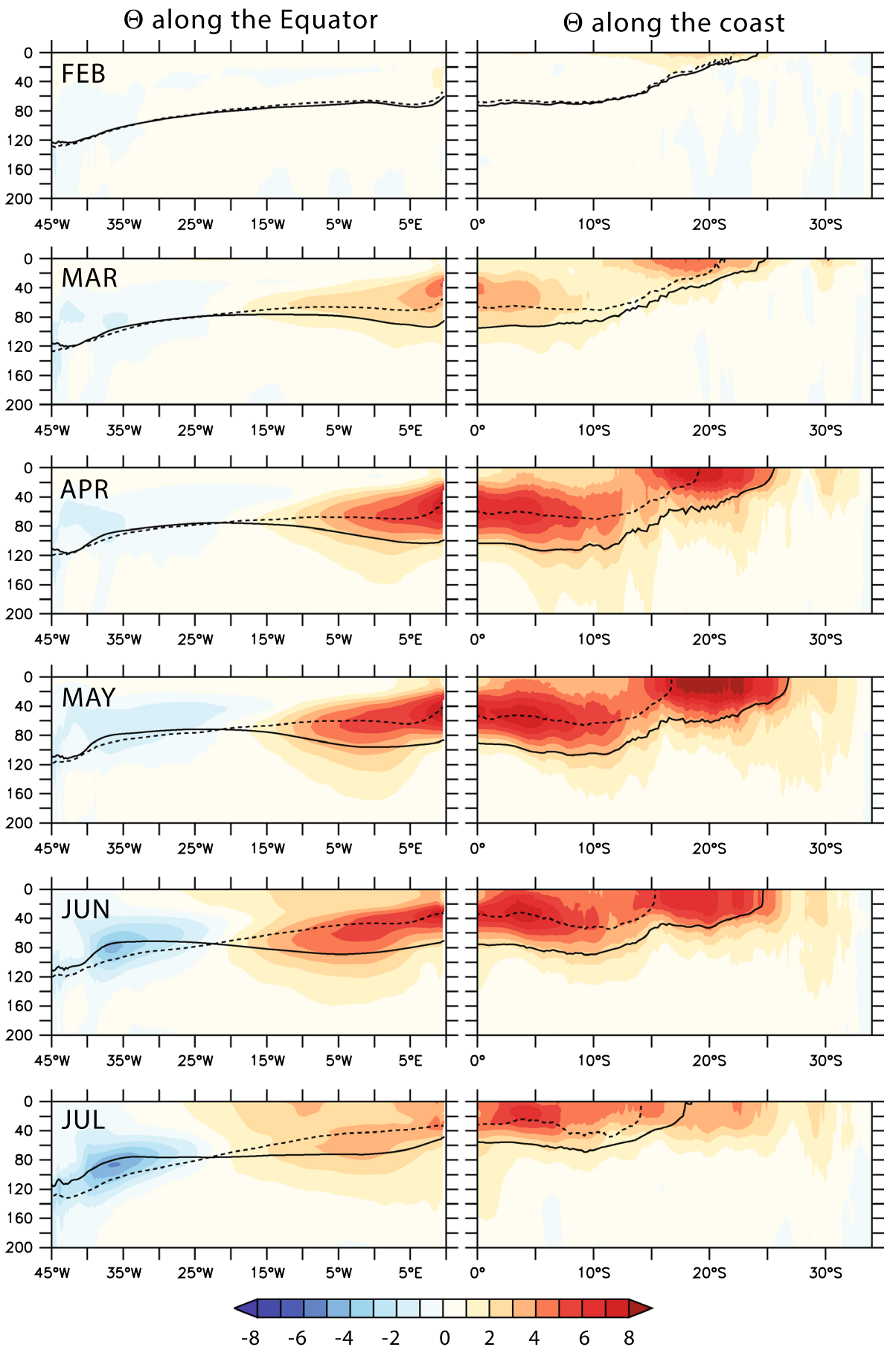

slowly decreases down to only $27.2{ }^{\circ} \mathrm{C}$, reflecting model deficiencies in simulating the cold tongue.

The analysis of the mixed layer tendency terms in CTRLHR (Fig. 7a) suggests that during the first 5 months of the hindcast the mixed layer temperature evolution is mostly driven by surface net heat flux (FORC), the latter being positive in February-March, negative from April to June and positive again in July. From February to April the cooling contribution of vertical mixing (MIX) is partly balanced by the residual term (RES), that contributes to a warming throughout the whole hindcast. From the end of May the contribution of MIX to cooling increases and allows for the continued decrease of the mixed layer temperature in June-July, in spite of a warming contribution by horizontal advection (XY-ADV) and RES, as well as a warm contribution by FORC in July.

In TAU-EQ the SST evolution (purple line in Fig. 6 (left)) in February-March is quite similar to CTRL-HR, although the bias is smaller by approximately $0.5^{\circ} \mathrm{C}$. However, the subsequent cooling is more rapid than in CTRL-HR, so in 
Fig. 5 Same as Fig. 4 but for the TAU-EQ experiment
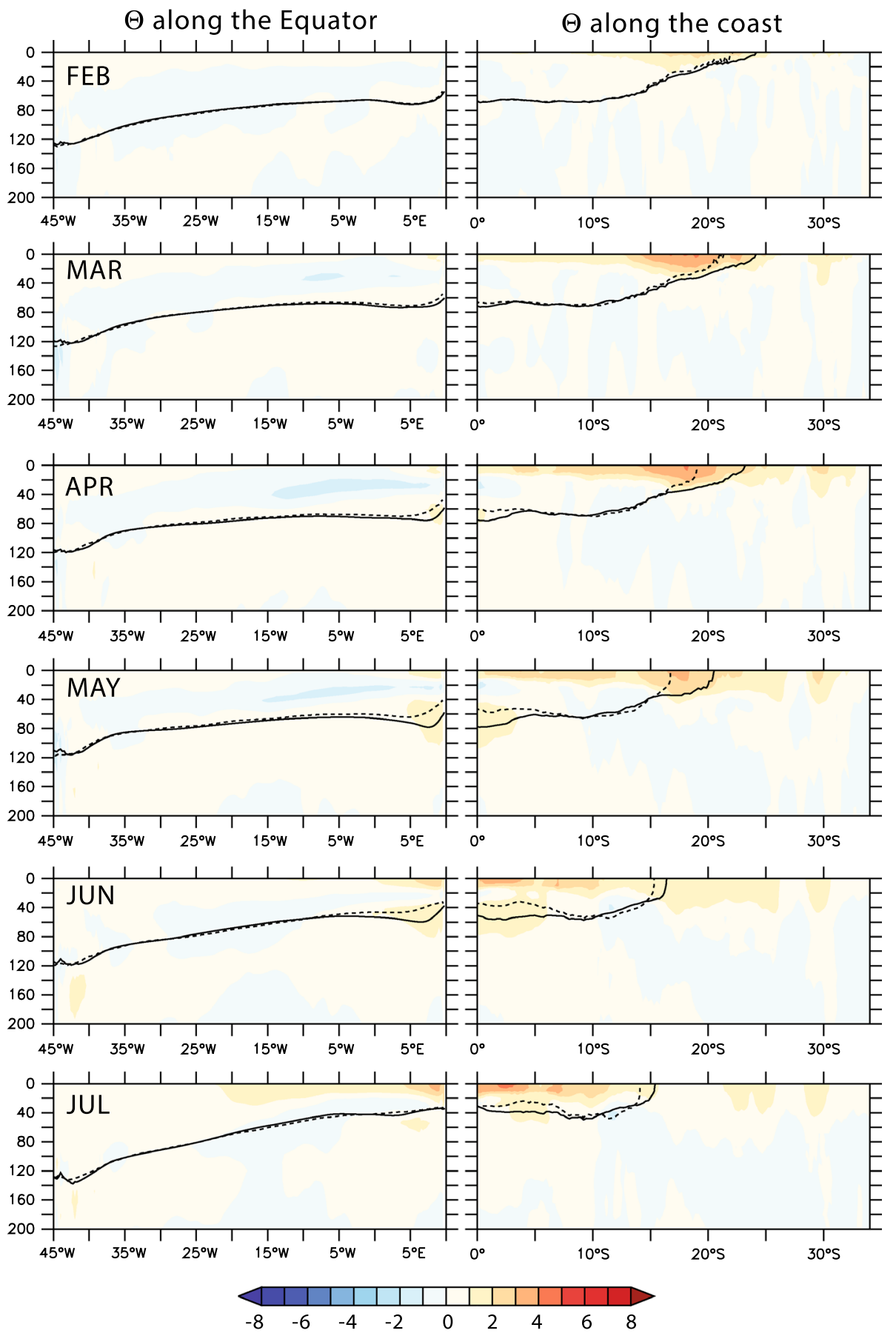

June-July the bias in TAU-EQ is reduced by $48 \%$ compared to CTRL-HR. This improvement is associated with drastic modifications in the mixed layer temperature heat budget (Fig. 7b).

Indeed, now FORC is a warming term throughout the whole hindcast. Although in February-March the temperature evolution is dominated by FORC, the relative contribution of this term is reduced relative to CTRL-HR due to a stronger negative MIX $\left(-0.045^{\circ} \mathrm{C} /\right.$ day in TAU-EQ relative to $-0.025{ }^{\circ} \mathrm{C} /$ day in CTRL-HR). At the end of April the contribution of MIX to cooling starts to rapidly increase and reaches about $-0.12{ }^{\circ} \mathrm{C} /$ day on average in June-July. In CTRL-HR, during this latter period the contribution of MIX is about three times smaller. Note also a negative contribution of the vertical advection (Z-ADV) in TAU-EQ in June-July which is, although small, nonetheless stronger than an almost zero Z-AVD in CTRL-HR.

Evolution of FORC and MIX in TAU-EQ are consistent with the seasonal mixed layer heat budget documented by previous modeling and observational studies in terms of 

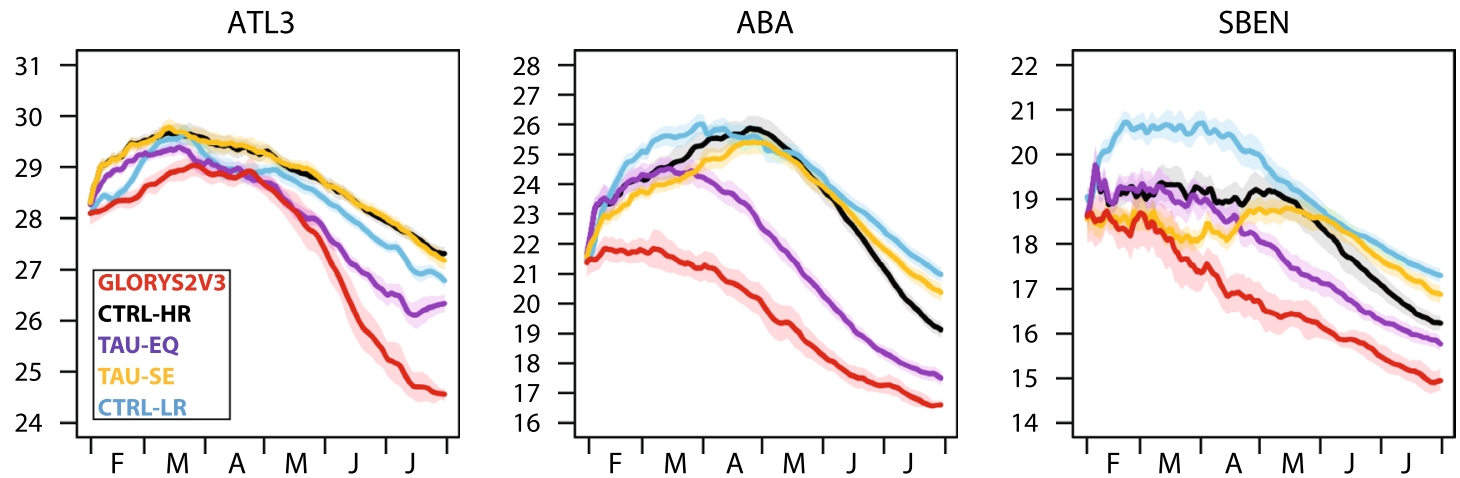

Fig. 6 Daily mean SST evolution in GLORYS2V3, control hindcasts and hindcasts corresponding to different sensitivity experiments averaged over the three boxes (from left to right: ATL3, ABA, SBEN): red-GLORYS2V3, black-CTRL-HR, purple-TAU-EQ, orangeTAU-SE, cyan-CTRL-LR. Cf. Table 1 and Fig. 2 for the experiment descriptions and definition of the boxes. Shaded areas denote the hindcast mean \pm standard error of the ensemble spread. In the case of GLORYS2V3 the standard error is calculated based on 10 years of data. Unit: ${ }^{\circ} \mathrm{C}$ (a) CTRL-HR
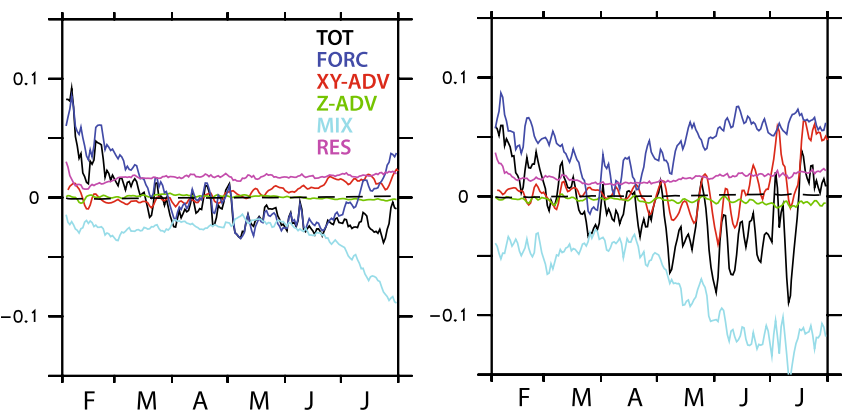

Fig. 7 Evolution of the daily-mean mixed layer temperature tendency terms averaged over the ATL3 box in different experiments (from left to right: CTRL-HR, TAU-EQ, TAU-SE, CTRL-LR; cf. Table 1 and Fig. 2 for the experiment descriptions and definition of the boxes):

their magnitudes as well as the timing of the MIX minimum, the latter being generally considered as the most important contributor to the seasonal cooling of the cold tongue (e.g. Peter et al. 2006; Jouanno et al. 2011; Giordani et al. 2013; Hummels et al. 2014; Schlundt et al. 2014; Planton et al. 2018). Previous studies also suggest that, along with FORC and MIX, XY-ADV contributes significantly to the mixed layer heat budget in the Eastern equatorial Atlantic, although its role in the development of the cold tongue is still under debate (cf. Planton et al. 2018 for the literature overview). In our hindcasts XY-ADV is almost zero in February-April, whereas in May-July it contributes on average to warming. This warming contribution is due to the zonal advection which is mainly related to mean currents. The meridional advection associated with tropical instability waves (TIW) shows a weak cooling tendency (not shown).

Note that due to the imposed ERA-Interim wind stress forcing, which is the same for each of the three ensemble (c) TAU-SE
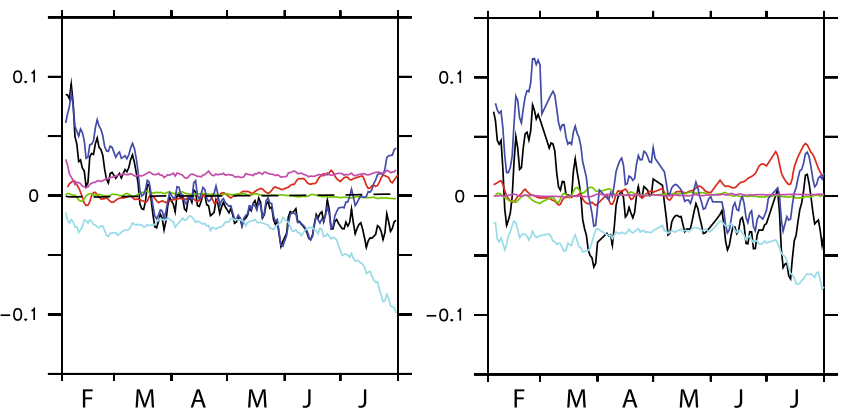

black-total temperature tendency (TOT), blue-atmospheric forcing (FORC), red-horizontal advection (XY-ADV), green-vertical advection (Z-ADV), cyan-vertical mixing (MIX), magenta-residual (RES) that includes entrainment. Unit: ${ }^{\circ} \mathrm{C} /$ day

members of a given hindcast year, the ensemble means of the terms depending on wind (e.g. MIX, XY-ADV) in the equatorial region in TAU-EQ correspond in fact to averaging of only 10 instead of 30 members in the fully coupled CTRL-HR. Consequently, the ensemble means for these terms exhibit more variability in TAU-EQ than in CTRL-HR.

\subsection{Remote equatorial forcing of the SETA SST bias (ABA box)}

Next, it will be examined through which processes the equatorial errors impact the SST in the coastal SETA regions. The main focus here is on the ABA box where CTRL-HR exhibits the strongest bias.

The observed SST in ABA (red line in Fig. 6 (middle)) is almost constant around $21.3{ }^{\circ} \mathrm{C}$ during the first 6 weeks of the hindcast and then it starts to gradually decrease down 
to $16.5^{\circ} \mathrm{C}$ at the end of July. CTRL-HR shows very different behavior (black line): a very rapid increase in SST by $1.8^{\circ} \mathrm{C}$ during the first week is followed by further warming for 3 months with SST reaching $26^{\circ} \mathrm{C}$ at the end of April. From the beginning of May the SST starts to decrease and falls to $19^{\circ} \mathrm{C}$ at the end of the hindcast.

Consistently with the evolution of SST, the TOT term for CTRL-HR (Fig. 8a) shows a warming tendency from the beginning of the hindcast until the end of April with subsequent cooling. This evolution is controlled to a large extent by FORC, although in February-March this term is partly balanced by strong negative MIX as well as weak negative XY-ADV and ZADV. During April the cool contribution of MIX decreases drastically from -0.1 to $-0.01{ }^{\circ} \mathrm{C} /$ day and then slowly increases again to reach $-0.05^{\circ} \mathrm{C} /$ day in July. A prominent feature of the mixed-layer heat budget is a strong warm contribution of XY-ADV that appears at the beginning of March, peaks at the end of April with a maximum of $0.14{ }^{\circ} \mathrm{C} / \mathrm{day}$, and then decays to become negative in midJune-July. The evolution of XY-ADV in ABA is in phase with the evolution of the SST bias (Fig. 3a).

Analysis of TAU-EQ further proves that the anomalous warm horizontal advection in CTRL-HR is induced by a remote equatorial forcing and explains, to a large extent, the strong warm SST bias. Indeed, as seen in Fig. 6 (middle), ABA SST in TAU-EQ (purple line) evolves exactly in the same way as in CTRL-HR during approximately the first 6 weeks of the hindcast, but from mid-March, when the SST reaches $24.5^{\circ} \mathrm{C}$, its evolution changes showing a cooling tendency with SST about $23{ }^{\circ} \mathrm{C}$ at the end of April and about $17.5^{\circ} \mathrm{C}$ in July. On average in March-May the SST bias is reduced by $57 \%$ with respect to CTRL-HR. This is associated with a total disappearance of the strong warm contribution of XY-ADV in the mixed layer budget (Fig. 8b). Now XY-ADV contributes to cooling all through the hindcast. Note also a stronger cooling contribution by MIX in April-July, as well as by Z-ADV in March-April, the latter being discussed in more detail in Sect. 4.1. At the same time, in TAU-EQ the contribution of FORC is positive till the end of April and then close to zero, whereas in CTRLHR it is positive in February-March and then contributes to strong cooling. In the Sect. 6 it will be shown that this mainly reflects the response of turbulent fluxes to lower SST and does not imply any SST-cloud feedback.

\section{SETA SST bias and wind-driven coastal upwelling}

Next, the role of the wind-driven coastal upwelling in the evolution of the SETA SST bias will be examined. In the SETA upwelling region the alongshore winds blowing in the equatorial direction induce offshore Ekman transport. Since the mass conservation requires that the surface water displaced by Ekman transport must be replaced by colder water from below, the alongshore winds control the intensity of vertical velocity. Moreover, vertical velocities in the ocean can also be induced by Ekman pumping when the near-coastal wind stress patterns are associated with a cyclonic curl resulting from the weakening of the wind toward the coast. In terms of heat budget analysis, in the coastal upwelling regions the role of the coastal upwelling in the mixed layer temperature evolution can thus be characterized through the advection terms, horizontal and vertical, contributing to cooling of the mixed layer. In the following the relative roles of these terms in the SETA SST evolution in the CTRL-HR and TAU-EQ experiments will be compared, and then, based on the TAU-SE experiment, the sensitivity of the SETA SST bias to the local wind stress will be evaluated.

\subsection{Mixed layer processes in the Benguela upwelling region: CTRL-HR versus TAU-EQ}

The SBEN box $\left(25^{\circ} \mathrm{S}-34^{\circ} \mathrm{S}\right)$ lies southward of the mean location of the ABFZ in both, CTRL-HR and TAU-EQ (Fig. 3a, b), suggesting that the simulated oceanic circulation in these experiments is dominated by the cold Benguela (a) CTRL-HR

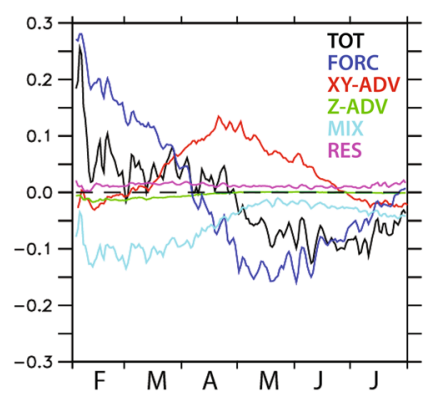

(b) TAU-EQ

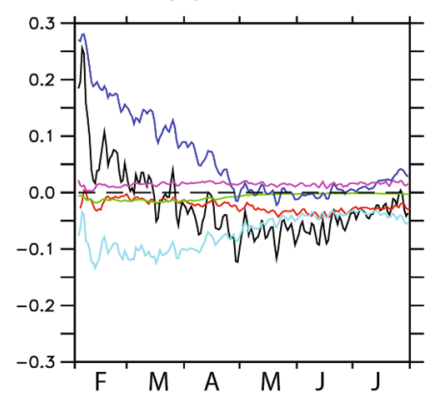

(c) TAU-SE

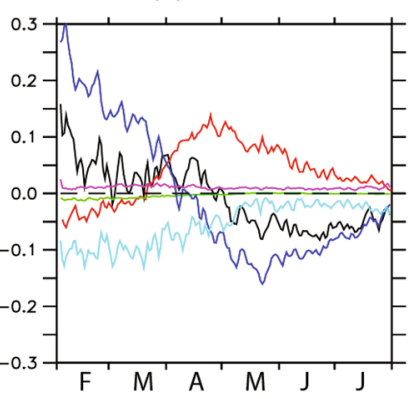

(d) CTRL-LR

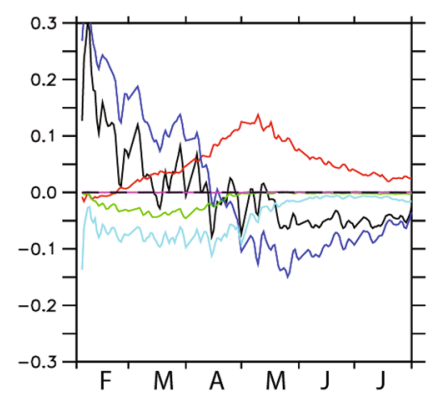

Fig. 8 Same as Fig. 7 but for the ABA box 
current and coastal upwelling. The evolution of the observed SST in the SBEN box (red line in Fig. 6 (right)) shows an almost linear cooling from 18.5 to $15^{\circ} \mathrm{C}$ over the period of the hindcast. In CTRL-HR the SST remains almost constant near $19{ }^{\circ} \mathrm{C}$ until mid-May and only then it starts to decrease down to $16.5^{\circ} \mathrm{C}$ at the end of the hindcast. TAU-EQ shows similar behavior but the cooling tendency starts approximately 1.5 months earlier, at the beginning of April, and at the end of July the SST is about $0.5^{\circ} \mathrm{C}$ cooler than in CTRL-HR.

The mixed layer heat budget analysis (Fig. 9a) for CTRL-HR shows that over the SBEN box the beginning of the hindcast is in general associated with a strong warm FORC $\left(\sim 0.35{ }^{\circ} \mathrm{C} /\right.$ day $)$ balanced by strong negative XY-ADV $\left(\sim 0.16^{\circ} \mathrm{C}\right)$ and $\mathrm{MIX}\left(\sim 0.2{ }^{\circ} \mathrm{C} /\right.$ day $)$ as well as by a weak negative ZADV $\left(\sim 0.05{ }^{\circ} \mathrm{C} /\right.$ day $)$. The strong contributions of these terms to the rate of mixed-layer temperature change decrease rapidly during the first half of the hindcast. During the second half of the hindcast the absolute values of their contributions vary from 0 to $0.07^{\circ} \mathrm{C} /$ day, with FORC having a stronger contribution (cooling) and controlling to a large extent the rate of the mixed layer temperature change. Note a slight warm contribution of XY-ADV between the end of April and beginning of June, suggesting that the equatorial forcing impacts the coastal region as far as south of $25^{\circ} \mathrm{S}$. Indeed, in TAU-EQ this warm contribution of XY-ADV is not found (Fig. 9b). Additionally, the negative contribution of ZADV is observed until the end of May in TAU-EQ instead of the end of April in CTRL-HR.

In order to better understand the role of heat advection processes in the evolution of the SST bias, the spatial distribution of the advection terms in the SETA region is analyzed. Consistently with the results above, Fig. 10 demonstrates that in the Benguela upwelling system the horizontal advection term in the model can be related to two different processes that have opposite effects on the changes of the mixed layer temperature: (1) cold horizontal advection associated with equatorward alongshore and offshore horizontal velocities related to Ekman transport; and (2) warm horizontal advection related, to a large extent, to equatorial forcing (as it has been shown in the Sect. 3) and associated with southward alongshore and offshore horizontal velocities. As shown in the previous analysis, the relative contributions of these two processes to the SST evolution along the coast are very different between TAU-EQ and CTRL-HR. Indeed, in February-March, in CTRL-HR cold advection dominates over the Southern Benguela region, whereas over the Northern Benguela region, corresponding to the ABA box, warm advection appears locally in the ABF zone (Fig. 10a). TAU-EQ shows similar patterns, although the warm advection and southward current in the Northern Benguela region are weaker (Fig. 10b). In April-May the surface coastal circulation is completely different between CTRLHR and TAU-EQ. In CTRL-HR a strong southward current associated with a warm XY-ADV dominates over the ABA region and propagates as far as south of $25^{\circ} \mathrm{S}$ (Fig. 10e). In TAU-EQ the upwelling regime prevails in both the Southern and Northern Benguela regions except for a small nearcoastal area between $15^{\circ} \mathrm{S}$ and $18^{\circ} \mathrm{S}$ where a weak warm $\mathrm{XY}-\mathrm{ADV}$ is still present (Fig. 10f). In June-July the warm advection decays in CTRL-HR allowing the development of a relatively weak alongshore northward current associated with weak cold advection, except for a small area between $15^{\circ} \mathrm{S}$ and $18^{\circ} \mathrm{S}$ characterized by weak warm advection (Fig. 10i). In TAU-EQ the prevailing alongshore cold advection is stronger than in CTRL-HR, particularly in the northern part of the Benguela upwelling system, and the warm advection almost disappears (Fig. 10j).

The evolution of the vertical advection terms in CTRLHR and TAU-EQ (Fig. 11) is consistent with the evolution of the corresponding cold horizontal advection terms, both terms being principally associated with Ekman dynamics. Thus, in February-March both hindcasts show relatively strong cold vertical advection (Fig. 11a, b). In April-May this term is still strong in TAU-EQ (Fig. 11f) but negligible in CTRL-HR (Fig. 11e), in spite of on average comparable magnitudes of vertical velocities (Fig. 12e, f). Indeed, due to anomalous equatorial remote forcing in CTRL-HR (a) CTRL-HR

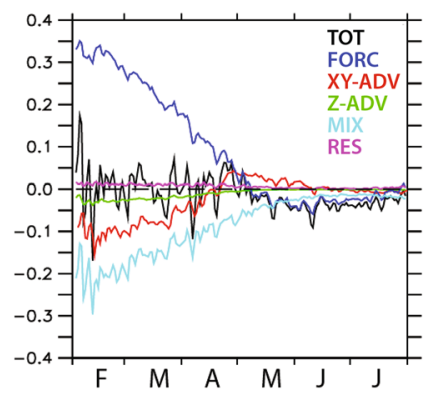

(b) TAU-EQ

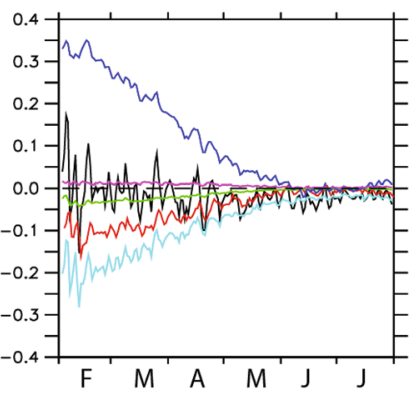

(c) TAU-SE

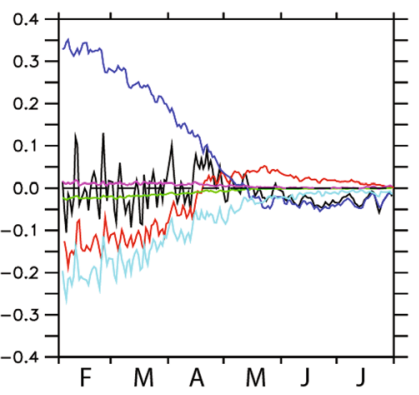

(d) CTRL-LR

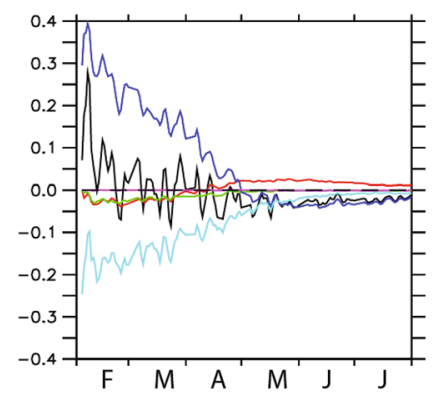

Fig. 9 Same as Fig. 7 but for the SBEN box 


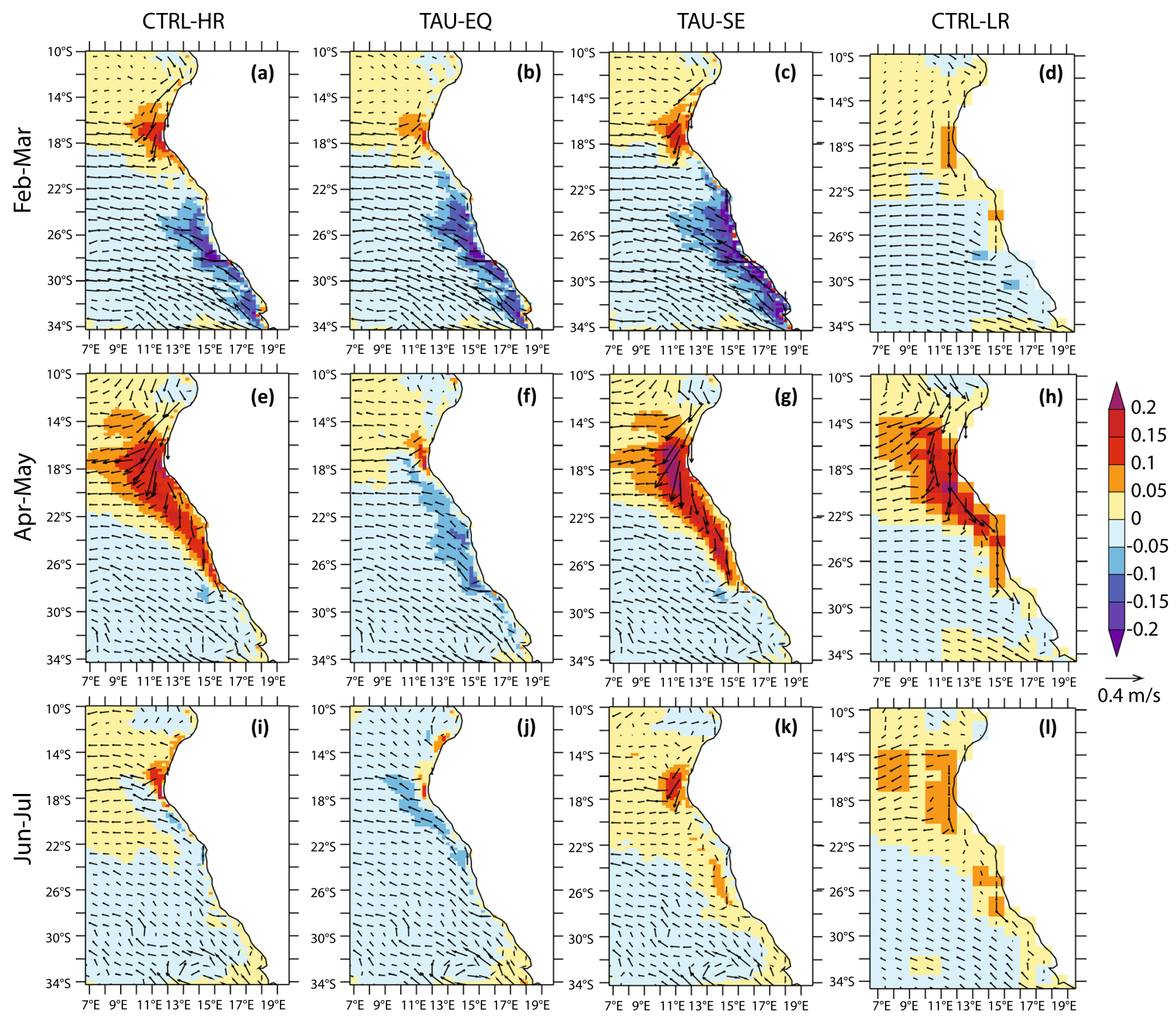

Fig. 10 Mean horizontal advection term of the mixed-layer heat budget (shading, ${ }^{\circ} \mathrm{C} /$ day) and surface current (arrows, $\mathrm{m} / \mathrm{s}$ ) averaged over (from top to bottom) February-March, April-May and June-July in (from left to right columns) CTRL-HR, TAU-EQ, TAU-SE and CTRL-LR

(cf. Sect. 3.3) the waters upwelled from below to the mixed layer, whose depth in this period in CTRL-HR is between 15 and $30 \mathrm{~m}$, are anomalously warm (Fig. 4). By consequence, the vertical temperature gradient is reduced and vertical advection is close to zero. A similar situation is observed in CTRL-HR in June-July: a strong warm subsurface bias, although reduced with respect to April-May (Fig. 4), is associated with a vertical advection close to zero (Fig. 11i). Despite the fact that TAU-EQ does not exhibit strong subsurface bias in June-July (Fig. 5) the vertical advection in this experiment is also weak (Fig. 11j). The latter can be explained by seasonal weakening of upper-ocean stratification associated with the seasonal cycle in solar radiation (Goubanova et al. 2013).
Note that the maximum of the vertical velocity (Fig. 12) and, by consequence, of the vertical advection term (Fig. 11) is located very close to the coast, basically over the 1-2 closest oceanic grid cells to the coast. Because of this, the contribution of the vertical advection to the mixed layer temperature change averaged over the ABA (Fig. 8) and SBEN (Fig. 9) boxes of $4^{\circ}$ - and $2^{\circ}$ width, respectively, is relatively small, with respect to other terms, whose spatial distributions are more uniform over the considered boxes.

\subsection{Sensitivity of the remotely forced SETA SST bias to local wind forcing: TAU-SE}

In order to evaluate the sensitivity of the remotely forced SST bias in the Benguela upwelling region to local 

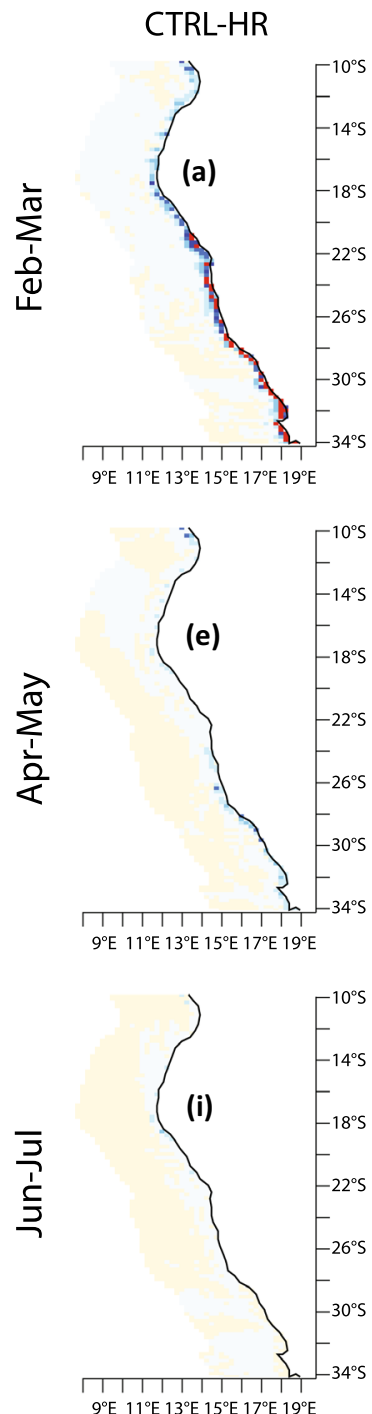
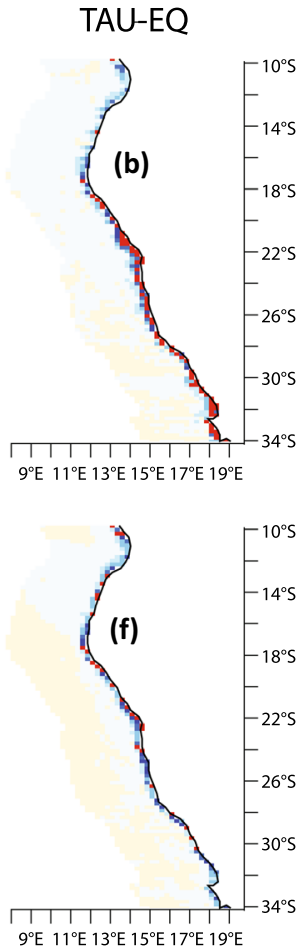

TAU-SE
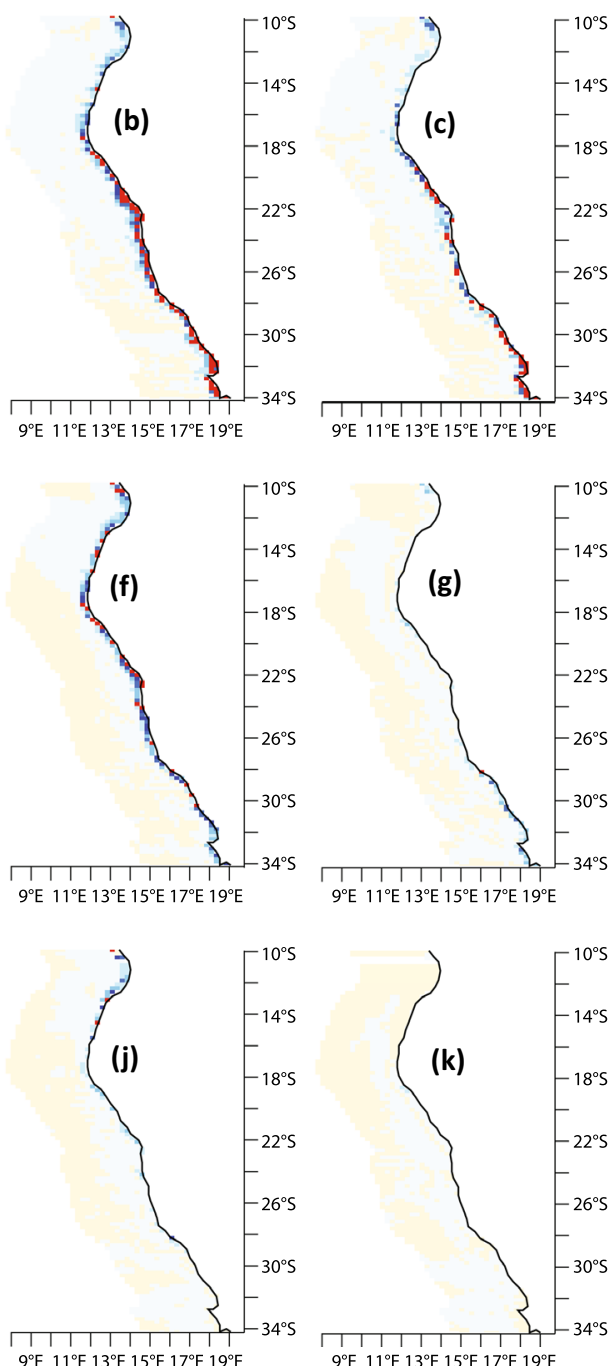

CTRL-LR
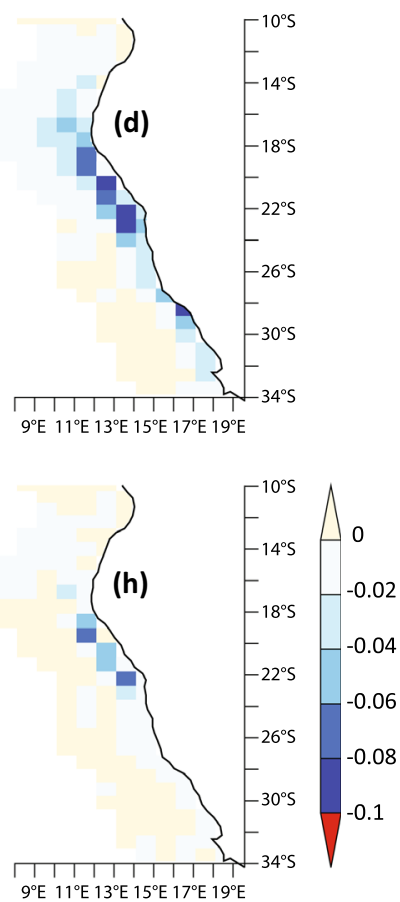

$9^{\circ} \mathrm{E} 11^{\circ} \mathrm{E} 13^{\circ} \mathrm{E} 15^{\circ} \mathrm{E} 17^{\circ} \mathrm{E} 19^{\circ} \mathrm{E}$

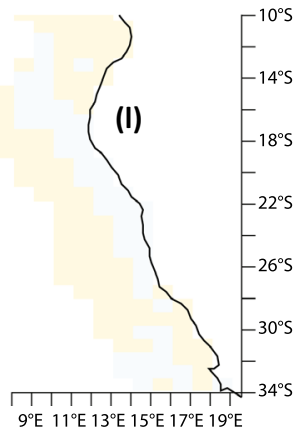

Fig. 11 Mean vertical advection term of the mixed-layer heat budget $\left({ }^{\circ} \mathrm{C} /\right.$ day) averaged over (from top to bottom) February-March, April-May and June-July in (from left to right columns) CTRL-HR, TAU-EQ, TAU-SE and CTRL-LR

dynamical forcing the TAU-SE sensitivity experiment has been performed. In TAU-SE the wind stress from ERAInterim was prescribed to the oceanic component of the model locally in the SETA region (cf. Sect. 2.2 for the experiment description).

First, the local errors in the wind stress in CTRL-HR with respect to QuikSCAT wind stress are computed. The climatological 2-months averaged evolution of the satellitederived wind stress over the period of the hindcast is shown in Fig. 13a, f, k. It reveals two coastal maxima, at Luderitz $\left(27^{\circ} \mathrm{S}\right)$ in the Southern Benguela region and Cape Frio $\left(17^{\circ} \mathrm{S}\right)$ in the Northern Benguela region, corresponding to the two strongest upwelling cells observed along the coast (Lutjeharms and Meeuwis 1987). Figures 13a, f, k illustrate a seasonal shift of the regional wind system in response to the seasonal northward migration of large-scale pressure systems: in February-March the wind stress is stronger in the southern part of the Benguela system than in its northern part, whereas from April to July the opposite is the case. These observed features (the two maxima and seasonal shift) are qualitatively well reproduced in the CTRL-HR hindcast (Fig. 13b, g, 1). They are also reflected by the seasonal evolution of the upwelling along the coast (Fig. 12a, e, i): in February-March the maximum vertical velocities are observed over the Luderitz area, whereas in April-July the maximum vertical velocities are located over the Cape Frio area. In terms of magnitudes, CTRL-HR overestimates the wind stress with respect to QuikSCAT south of $18^{\circ} \mathrm{S}$. In particular, in a $2^{\circ}$-wide strip off coast on between $18^{\circ} \mathrm{S}$ and $34^{\circ} \mathrm{S}$, on average over the period of the hindcasts, the alongshore wind stress is $0.086 \mathrm{~Pa}$ in CTRL-HR and 0.051 Pa in QuikSCAT. Over Cape Frio and further north the modeled wind 

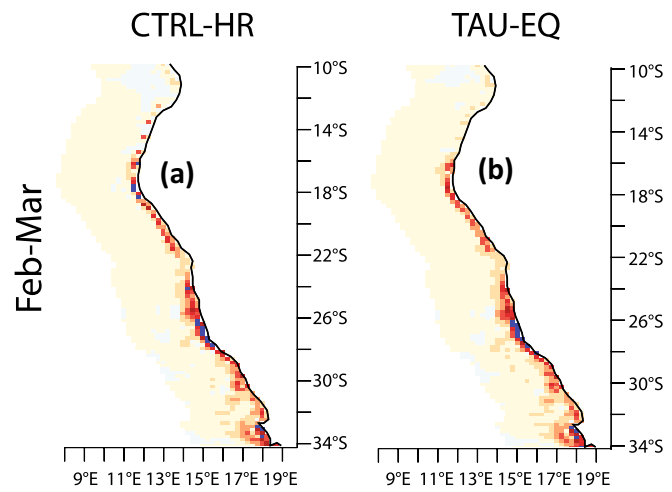

TAU-SE
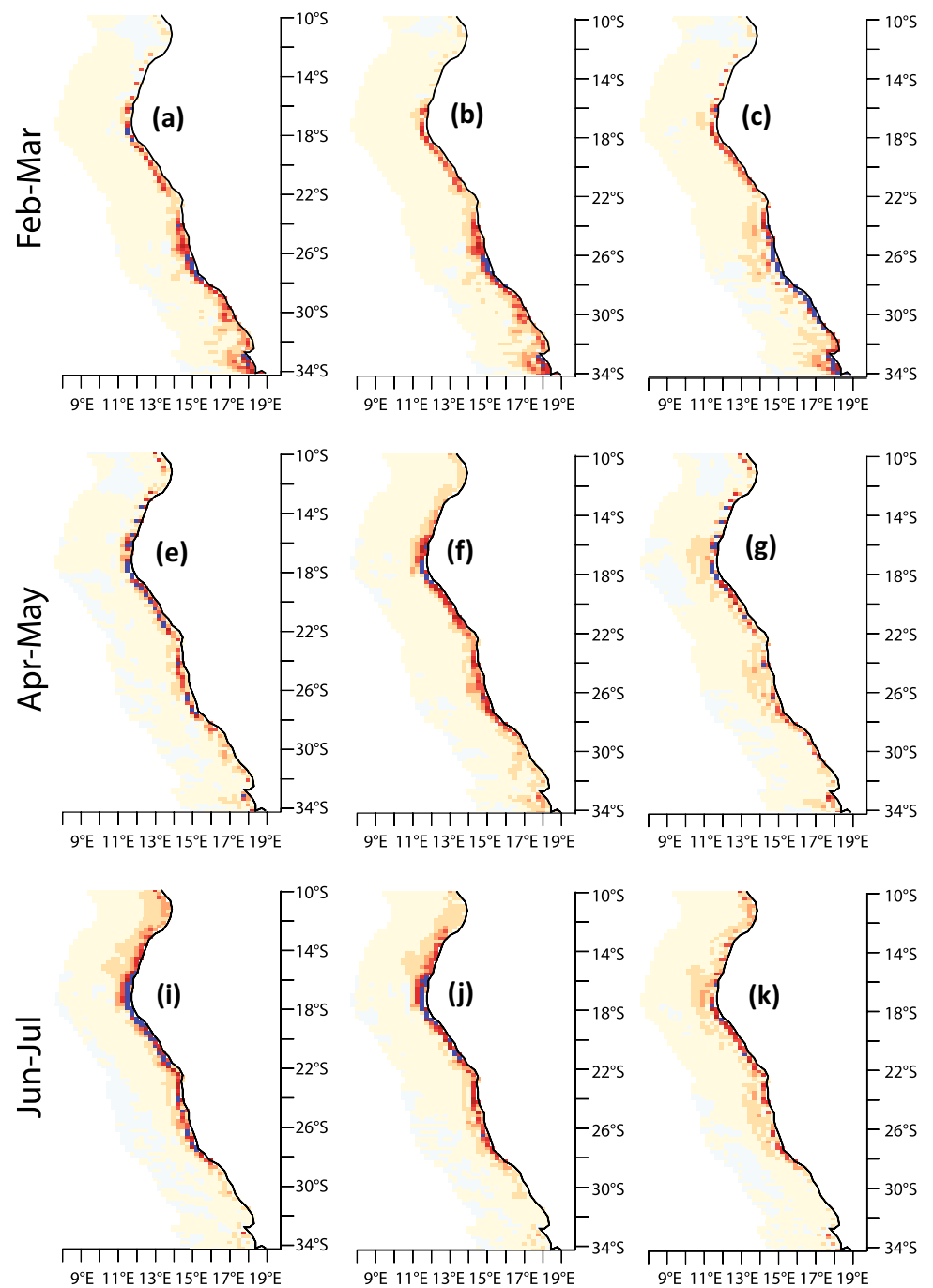

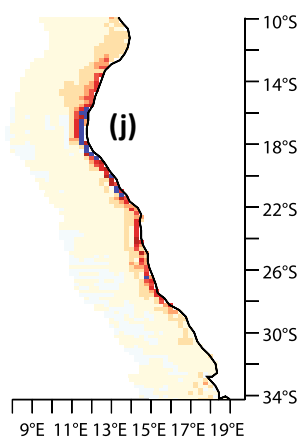

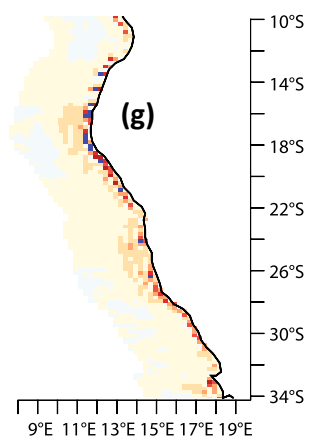

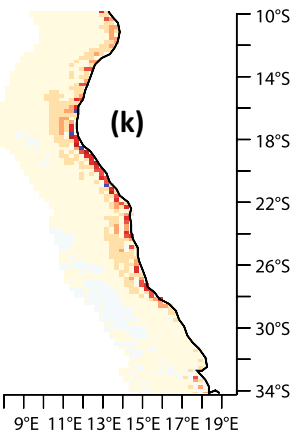

CTRL-LR
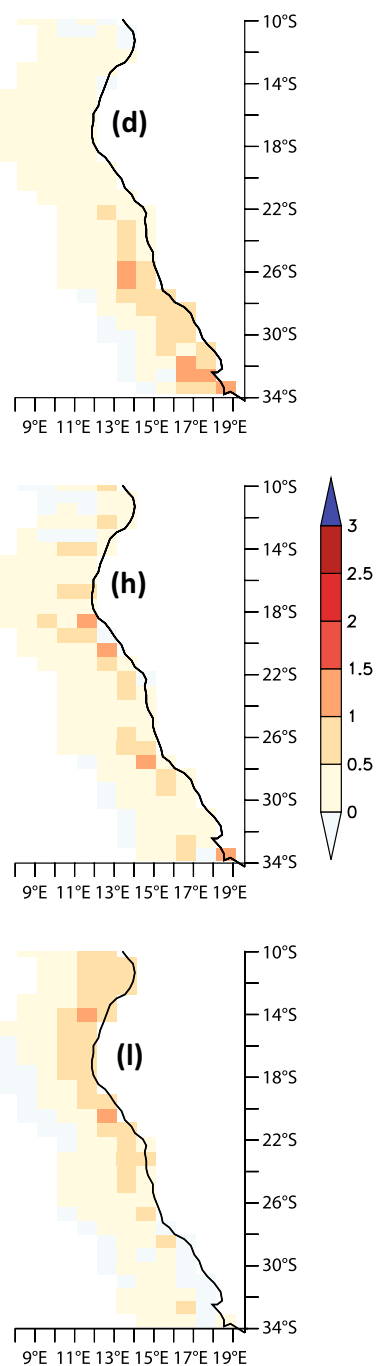

Fig. 12 Mean maximum vertical velocity between 10 and $100 \mathrm{~m}$ (m/day) averaged over (from top to bottom) February-March, April-May and June-July in (from left to right columns) CTRL-HR, TAU-EQ, TAU-SE and CTRL-LR

stress is weaker with respect to the satellite product from February to May, but is strongly overestimated in June-July. For instance, in the extreme northern part of the Benguela system between $15^{\circ} \mathrm{S}$ and $18^{\circ} \mathrm{S}$ in a $2^{\circ}$-wide strip off the coast, the mean wind stress in February-May is $0.076 \mathrm{~Pa}$ in CTRL-HR and 0.084 Pa in QuikSCAT, whereas in June-July the mean wind stress in CTRL-HR is 0.134 and $0.074 \mathrm{~Pa}$ in QuikSCAT. Note also that the local wind stress maximum off Cape Frio is located too far offshore with respect to QuikSCAT, the latter showing the maximum just near the coast.

The ERA-Interim wind stress used in the TAU-SE experiment shares some similar biases with CTRL-HR with respect to QuikSCAT. In particular, despite a general overestimation of the wind stress over the Benguela region, the local maximum off Cape Frio is underestimated and located too far offshore (Fig. 13c, h, m). Compared to CTRL-HR, the ERA-Interim wind stress is even more intense in February-March (by 8 and $13.7 \%$ over the ABA and SBEN regions, respectively), but weaker from April to July, especially in June-July (by 20.4 and $6.4 \%$ over the ABA and SBEN regions, respectively). In contrast to CTRL-HR, ERA-Interim does not exhibit a strong increase in wind in June-July over the Cape Frio region, although the wind stress is still slightly overestimated with respect to QuikSCAT (0.09 Pa in ERA-Interim on average between $15^{\circ} \mathrm{S}$ and $18^{\circ} \mathrm{S}$ in a $2^{\circ}$-wide strip off the coast).

Given the differences in wind stress between ERAInterim and CTRL-HR, the further analysis of the TAUSE experiment aims at answering two main questions: (1) can prescribing the stronger ERA-Interim wind stress in February-March over the Benguela region slow down the development of the local SST bias? and (2) is the apparent 


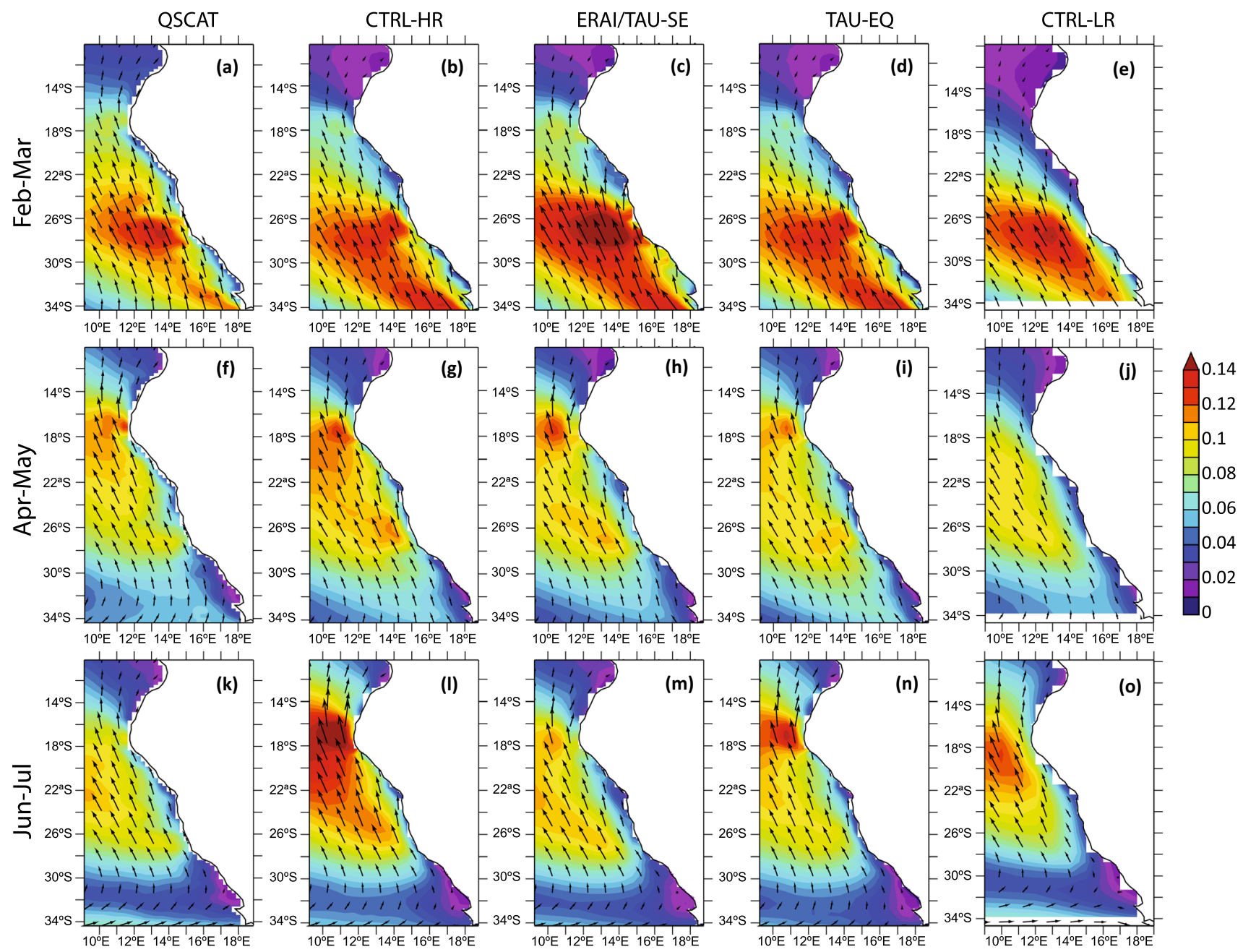

Fig. 13 Mean wind stress averaged over (from top to bottom) February-March, April-May and June-July in (from left to right columns) QuickSCAT, CTRL-HR, TAU-SE (corresponding to the wind stress

weakening of the SST bias in CTRL-HR observed in June-July along the coast south of $15^{\circ} \mathrm{S}$ (Fig. 3a) due to the local overestimation of wind?

Figures $3 \mathrm{c}$ and 6 (middle, right) suggest that prescribing the wind stress from ERA-Interim over the SETA region leads to a slightly smaller bias in SST in the Benguela system from February to May. The difference in SST between CTRL-HR and TAU-SE in this period is $0.5^{\circ} \mathrm{C}$ in ABA and $0.6{ }^{\circ} \mathrm{C}$ in SBEN. In contrast, in June-July, TAU-SE shows a stronger bias than CTRL-HR (the mean difference in SST between the two experiments is $0.6{ }^{\circ} \mathrm{C}$ for both, SBEN and ABA). The analysis of the mixed-layer heat budget over ABA (Fig. 8a, c) and SBEN (Fig. 9a, c) further yields that the differences between CTRL-HR and TAU-SE consist mainly of different contributions from the XY-ADV term in the beginning (February-March) and at the end (June-July) of the hindcasts. from ERA-Interim remapped on the ORCA025 grid using bi-cubic interpolation), TAU-EQ and CTRL-LR. Shading and arrows indicate the wind stress amplitude and vector, respectively. Unit: $\mathrm{Pa}$

In the beginning of the hindcast period the appearance of the warm advection in ABA in March is delayed by approximately 2 weeks in TAU-SE with respect to CTRL-HR. By consequence, the cumulative contribution of XY-ADV to the mixed layer temperature changes over February-March is positive $\left(0.6{ }^{\circ} \mathrm{C} /\right.$ day $)$ in CTRL-HR but negative $\left(-1{ }^{\circ} \mathrm{C} /\right.$ day) in TAU-SE. This cool contribution is associated with a stronger local cold advection related to more intense winddriven upwelling and a weaker remote warm advection accompanied by a reinforced equatorward Benguela current (Fig. 10a versus c). Indeed, locally just near the coast, the Angola current extents as far as $24^{\circ} \mathrm{S}$ in CTRL-HR and "only" to $19^{\circ} \mathrm{S}$ in TAU-SE. In SBEN, the XY-ADV term contributes to cooling in both experiments but is about $35 \%$ stronger in TAU-SE than in CTRL-HR.

On the other hand, at the end of hindcast, in June-July, a weaker wind stress in TAU-SE with respect to CTRL-HR leads to a prevailing weak warm XY-ADV over the whole 
Benguela region and to an almost complete suppression of the equatorward alongshore current (Fig. 10i versus k). Note that along with the warm contribution of XY-ADV, a weaker contribution of MIX to cooling in TAU-SE (by 30 and $25 \%$ in ABA and SBEN, respectively, with respect to CTRL-HR) also contributes to maintaining the warm SST bias in June-July (Figs. 8a, c, 9a, c).

The local restoring of the wind stress in the SETA region and the associated change in SST in the SBEN do not have any impact on the equatorial region in terms of SST (Figs. 3a, c, 6a) and mixed layer heat budget (Fig. 7a, c). These results are consistent with the conclusions by Small et al. (2015) and Milinski et al. (2016), even though in our case the SETA SST difference between CTRL-HR and TAUSE is rather weak. In particular, Small et al. (2015) show that the remote effect from the SETA region to the Equatorial Atlantic is observed only when correcting the SST in a broad region, offshore of the south-western coast of Africa, which extends up to the equator, whereas an SST correction in a relatively narrow coastal upwelling zone outside the equatorial domain does not have any "upscaling" effect.

In addition to impacts from the modification of the alongshore wind stress amplitude on the intensity of coastal upwelling the wind stress curl may also play a role in the SETA SST bias. This will be discussed in the next section.

\section{Impact of the model resolution: CTRL-HR versus CTRL-LR}

In Sect. 3 it has been shown that the high-resolution model $\left(1 / 4^{\circ}\right.$ in the ocean and $0.5^{\circ}$ in the atmosphere) exhibits a similar magnitude of the warm SETA SST bias as the CMIP5 models (Toniazzo and Woolnough 2014; Richter 2015). This confirms conclusions of previous studies suggesting that higher resolution alone is not a solution to the SETA bias issue (e.g. Doi et al. 2012; Patricola et al. 2012; Zuidema et al. 2016). However, an accurate evaluation of whether and to what extent higher resolution can partially improve the SETA SST bias requires a comparison with a coarser-resolution version of the same model. Thus the control hindcast experiments have also been performed with a lower resolution version $\left(1^{\circ}\right.$ in the ocean and $1.4^{\circ}$ in the atmosphere) of the CNRM CGCM following exactly the same protocol used for CTRL-HR (cf. more details on the LR model and CTRL-LR experiment in Sect. 2).

Figure $3 d$ shows that CTRL-LR experiences very similar bias evolutions along the equator and along the coast as CTRL-HR, with only slight differences in magnitudes. Over the hindcast period, the mean SST error along the equator $\left(40^{\circ} \mathrm{W}-10^{\circ} \mathrm{E}, 2^{\circ} \mathrm{S}-2^{\circ} \mathrm{N}\right)$ is on average $0.8^{\circ} \mathrm{C}$ in CTRL-LR and $1.2^{\circ} \mathrm{C}$ in CTRL-HR, whereas along the coast $\left(34^{\circ} \mathrm{S}-0^{\circ} \mathrm{S}, 2^{\circ}\right.$-wide strip off the coast) the mean SST error is $3.8^{\circ} \mathrm{C}$ in CTRL-LR and $3.3{ }^{\circ} \mathrm{C}$ in CTRL-HR. The region with the strongest differences in SST bias between CTRLLR and CTRL-HR corresponds to the SBEN box, where the mean SST error is $1.6{ }^{\circ} \mathrm{C}$ in $\mathrm{HR}$ and $2.6{ }^{\circ} \mathrm{C}$ in LR.

The mixed-layer heat budget analysis is then used to investigate if the SETA SST evolution over the equator (ATL3) and along the coast (ABA and SBEN) in CTRL-LR is associated with the same processes as in CTRL-HR. Over ATL3 the errors in the mixed-layer heat budget in CTRLLR (Fig. 7d) are in general similar to those in CTRL-HR (Fig. 7a), compared to the more realistic hindcast TAU-EQ (Fig. 7b). The contribution of MIX to the mixed-layer budget is underestimated, especially during the June-July cooling, and the rate of the mixed-layer temperature changes is mainly controlled by FORC instead of XY-ADV. In contrast to CTRL-HR, the RES term is almost zero in CTRL-LR.

Over ABA, similarly to CTRL-HR, the temperature evolution in CTRL-LR (Fig. 8d) is associated with a spurious warm horizontal advection. Further south, over SBEN, the difference in the XY-ADV term between CTRL-LR and CTRL-HR becomes drastic (Figs. 9a, d, 10a, d). For instance, in February-March its contribution to cooling is about four times weaker in CTRL-LR than in CTRL-HR. This is associated with vanishing of the equatorward surface current (Fig. 10d) and a much weaker near-coastal vertical velocity (Fig. 12d) in CTRL-LR with respect to CTRL-HR (as well as with respect to the two other experiments with the HR model: TAU-EQ and TAU-SE). For instance, on average over the hindcast period the maximum vertical velocity between 10 and $100 \mathrm{~m}$ calculated at the most vigorous upwelling cell (Luderitz, 26-27 ${ }^{\circ} \mathrm{S}$ ) over the grid point closest to the coast is about $0.62 \mathrm{~m} /$ day in CTRL-LR compared to $3.47 \mathrm{~m} /$ day in CTRL-HR. However, even a weak vertical velocity may result in a relatively strong cooling of the mixed layer through vertical advection, if the upper ocean stratification is sufficiently strong. This is the case in particular in CTRL-LR in ABA in February-March (Figs. 8d, 11d).

In general, a better representation of the coastal upwelling circulation in CTRL-HR is first of all due to its higher oceanic resolution of $0.25^{\circ}$, which corresponds to a grid cell width of $19 \mathrm{~km}$ in the south of the SETA region and $27.6 \mathrm{~km}$ in the north, in comparison to a $1^{\circ}$ oceanic resolution of CTRL-LR, corresponding to $90-110.5 \mathrm{~km}$, respectively. Nevertheless, the quarter degree resolution of CTRL-HR remains still too coarse to accurately resolve the crossshore scale of coastal upwelling, which is estimated to be about $10 \mathrm{~km}$ in the Benguela region (Small et al. 2015; Marchesiello and Estrade 2010). Indeed, the local coastal maximum in vertical velocity in CTRL-HR of $3.47 \mathrm{~m} /$ day is notably weaker than the magnitudes of the annual mean upwelling rate of $11.7 \mathrm{~m} /$ day estimated by Veitch et al. (2009) within $30 \mathrm{~km}$ off the coast in the Luderitz area based on a simulation with a high resolution regional oceanic 
model $\left(1 / 12^{\circ}\right.$, corresponding to $7.5 \mathrm{~km}$ in the southern Benguela to $9 \mathrm{~km}$ in the northern Benguela) forced by QuickSCAT winds.

Along with the oceanic model resolution, the representation of the upwelling in the model strongly depends on the realism and resolution of the wind stress forcing (Cambon et al. 2013; Machu et al. 2015; Small et al. 2015; Milinski et al. 2016). Indeed, even averaged within $1^{\circ}$ off the coast the maximum vertical velocity in the Luderitz cell in CTRL-HR $(1.68 \mathrm{~m} /$ day $)$ is still significantly stronger than the $0.62 \mathrm{~m} /$ day of the corresponding maximum vertical velocity in CTRL-LR. Figure 13e, j, o shows that in CTRL-LR the wind stress field in the Benguela system exhibits shortcomings typical for coarse resolution atmospheric models (Machu et al. 2015; Patricola and Chang 2016): in general, too weak wind stress at the coast with the wind stress maximum located too far offshore and, in particular, a strongly underestimated local maximum of the wind stress over the Cape Frio region $\left(17^{\circ} \mathrm{S}\right)$. These local atmospheric errors certainly contribute to the underestimation of the coastal upwelling in CTRL-LR. In addition to the errors in upwelling-favorable alongshore wind stress, the LR model shows a too broad structure of the wind stress curl in the zonal direction from the coast (not shown). Small et al. (2015) argue that such a structure of wind stress results on long time scales in a southward coastal transport and weak coastal upwelling, both contributing to large warm SST biases in the SETA region.

At the same time, similarly to the results of Small et al. (2015), our high-resolution model experiments (CTRLHR, TAU-EQ and TAU-SE) generally overestimate the wind stress curl in the near-coastal region with respect to QuikSCAT satellite observations (not shown). As mentioned by Small et al. (2015) this should be partly explained by the contamination of the oceanic cells by winds from the land during the remapping procedure (cf. Sect. 2.2 for details of the remapping procedure in our models) or may be due to deficiencies in the representation of orography and other land surface features (Milinski et al. 2016). On the other hand, Astudillo et al. (2017) recently suggested for the Peru-Chile upwelling system that scatterometter-based products (such as QuickSCAT) strongly underestimate the strength of wind stress curl in the approximately $50 \mathrm{~km}$ wide near-coastal fringe.

\section{Discussion}

\subsection{Equatorial forcing of the SETA model bias and observed interannual warm events}

The results shown here indicate that for the CNRM CGCM, approximately half of the warm SETA SST bias is remotely forced by equatorial winds exhibiting a strong mean westerly bias. This wind error induces a thermocline deepening eastward from $25^{\circ} \mathrm{W}$. The associated warm subsurface temperature anomaly propagates along the thermocline and appears at the surface along the coast between $15^{\circ} \mathrm{S}$ and $20^{\circ} \mathrm{S}$, where the thermocline outcrops, from the second month of the hindcast. In the eastern equatorial Atlantic a warm SST bias appears only in June-July, when a seasonal shallowing of the thermocline allows subsurface-surface coupling. Previous studies (Richter et al. 2012; Xu et al. 2014b) suggested that the mechanism for the formation of the warm SETA biases in climate models resembled that of the development of interannual warm events that are induced by a relaxation of equatorial trade winds and that manifest themselves as a Benguela Niño in March-April-May (MAM), followed by an Atlantic Niño in the eastern equatorial region in June-July (Lübbecke et al. 2010; Imbol Kougue et al. 2017).

However, as mentioned by Toniazzo and Woolnough (2014), the magnitude of anomalies associated with the model bias in equatorial winds and SETA SST appears to be largely outside the observed range of natural variability. For instance, the mean SETA SST bias in CTRL-HR of more than $8{ }^{\circ} \mathrm{C}$ (averaged between $16^{\circ} \mathrm{S}$ and $24^{\circ} \mathrm{S}$ from the coast to $2^{\circ}$ and from mid-April to mid-May) greatly exceeds the SST anomalies observed even during the strongest Benguela Niño events. Imbol Kounge et al. (2017) showed that during 1998-2012, the warm monthly SST anomalies did not exceed $3{ }^{\circ} \mathrm{C}$ between $19^{\circ} \mathrm{S}$ and $24^{\circ} \mathrm{S}$ in a $1^{\circ}$-wide coastal fringe, whereas Florenchie et al. (2004) reported that, during a major Benguela Niño in 1995, the monthly SST anomalies in certain areas reached $5{ }^{\circ} \mathrm{C}$ (based on the OISST dataset). Similarly, although the observed interannual warm events result from a relaxation of the equatorial easterlies, westerly wind bursts (in terms of full wind field) have not been observed in the equatorial Atlantic (Seiki and Takayabu 2007). In contrast, in our model the mean equatorial winds are westerly from $20^{\circ} \mathrm{W}$ to the African coast at least from March to June (cf. blue arrows in Fig. 1). This wind bias severely alters the oceanic mean state at the equator leading to unrealistic stratification and mean currents, which affects the equatorial dynamics and, therefore, the oceanic teleconnections linking the equator with the coastal region.

In order to illustrate the oceanic teleconnections in the CTRL-HR hindcast associated with the erroneous oceanic mean state, Fig. 14a shows the CTRL-HR sea surface height anomalies (SSHA) with respect to the TAU-EQ mean seasonal cycle along the equator and along the coast for three individual hindcast years. For this example the years 2005, 2006 and 2007 are chosen since they do not exhibit interannual warm events along the coast during March-July (Imbol Kougue et al. 2017). First, Fig. 14a shows that consistently with a deeper mean thermocline (Fig. 4) CTRL-HR is characterized by a higher mean $\mathrm{SSH}$ in the eastern equatorial 
(a)

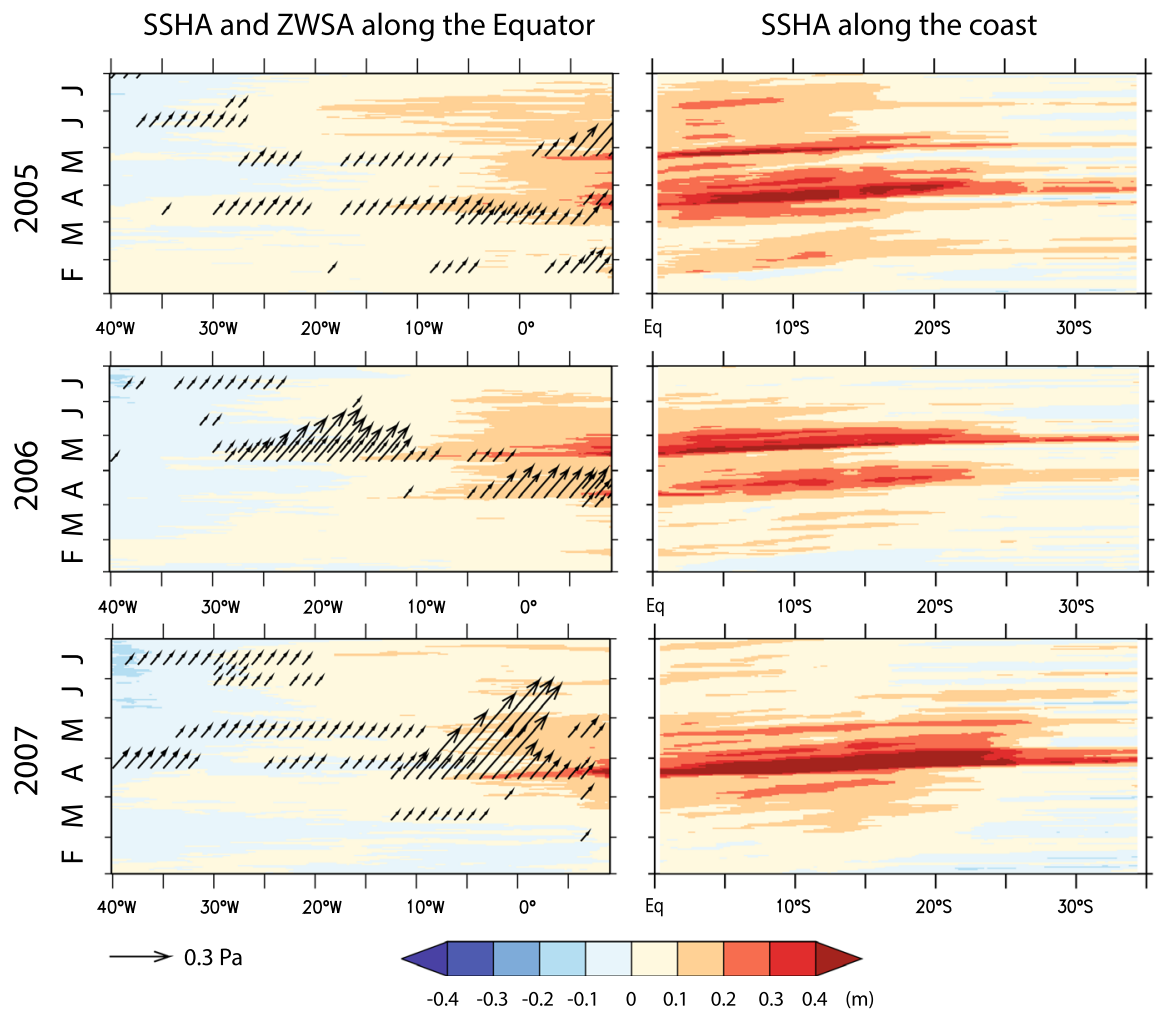

(b)
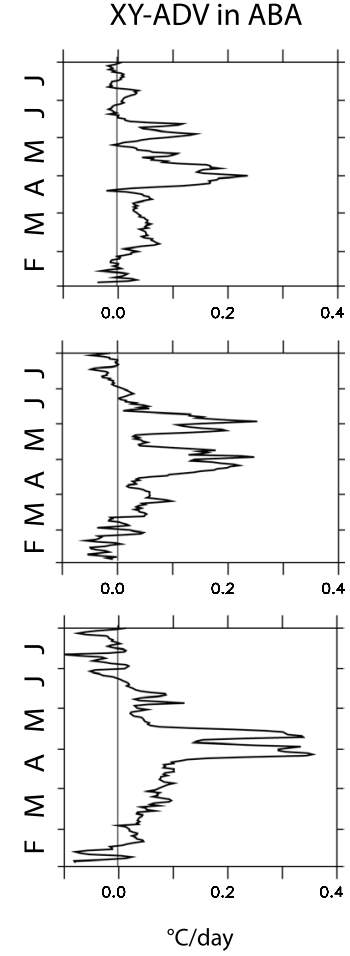

Fig. 14 a Evolution of the anomalies of sea surface height (SSHA, $\mathrm{m}$ ) in CTRL-HR with respect to the TAU-EQ seasonal cycle (left) along the equator and (right) along the south-western coast of Africa for the hindcast years (from top to bottom) 2005, 2006 and 2007. The first member for each year is shown. The corresponding anomalies of the zonal wind stress (ZWSA, Pa) along the equator are depicted in

Atlantic and along the coast, with respect to the much more realistic hindcast TAU-EQ. Second, CTRL-HR exhibits a pronounced intra-seasonal variability of SSHA, especially along the coast. This variability is associated with strong and rapid downwelling Kelvin waves induced at the equator by westerly wind bursts, propagating first eastward and then poleward along the coast as far as $34^{\circ} \mathrm{S}$. The magnitude of these waves is roughly 4-5 times stronger than the magnitude of the observed intraseasonal Kelvin waves (Polo et al. 2008) and they are roughly 2-3 times faster than the second baroclinic mode considered as the dominant mode in the eastern equatorial Atlantic (Illig et al. 2004). This behaviour is consistent with the fact that in a deeper thermocline, the intra-seasonal Kelvin waves are characterized by higher amplitude and propagate faster (e.g. Benestad et al. 2002). Along with a deeper thermocline in CTRL-HR, modified background currents may also influence the Kelvin waves speed through a Doppler shift.

Figure 14b further suggests that the coastal-trapped Kelvin waves (CTW) strongly influence the evolution of XYADV in ABA. Similarly to 2005, 2006 and 2007 shown in arrows, which are shown at $45^{\circ}$ for clarity. Only the ZWSA stronger than $0.04 \mathrm{~Pa}$ are shown. Along the coast, SSHA is averaged from the coastline to $0.5^{\circ}$ off the coast. b Evolution of the horizontal advection term $\left({ }^{\circ} \mathrm{C} /\right.$ day $)$ in $\mathrm{ABA}$ in CTRL-HR for the same members of the same hindcast years as in $\mathbf{a}$

Fig. 14a, b, in each member of each hindcast year in CTRLHR there is at least one downwelling CTW triggered by the westerly wind burst at the equator that induces a strong warm XY-ADV event of more than $0.12{ }^{\circ} \mathrm{C} /$ day (on average in $\mathrm{ABA}$ ) along the coast (not shown). This suggests that the ensemble mean horizontal advection that explains about half of the MAM SETA bias in CTRL-HR is not a gradual process but rather associated with strong intra-seasonal Kelvin waves, which propagate too rapidly and too far southward along the coast due to the erroneous ocean mean state at the equator, the latter resulting from the mean westerly wind bias in the model. Similarly to CTRL-HR, the ensemble mean warm XY-ADV in ABA in CTRL-LR is also explained to a large extent by propagations of strong and fast intraseasonal Kelvin waves in each member of each hindcast year (not shown).

Bachèlery et al. (2015) found that the temperature anomalies associated with interannual events along the coast were driven not only by horizontal advection but also by vertical advection. A negligible role of the vertical advection in the development of the warm SST bias in our model should 
be due to an unrealistic upper-ocean stratification along the coast associated with an upper ocean temperature bias induced by errors in both remote and local forcing. Note that the alongshore stratification also plays a fundamental role in the propagation characteristics of the CTW and may explain why intraseasonal CTW propagate as far as $34^{\circ} \mathrm{S}$ in CTRL-HR and CTRL-LR, whereas the observations show that on intraseasonal scales the equatorial connection fades at $12^{\circ} \mathrm{S}$ (Polo et al. 2008).

\subsection{Role of local errors in wind}

Although the processes responsible for the initial bias development in the SETA region observed during the first month of the hindcast were not investigated in detail in the present study, our analysis suggest that the initial development of the bias is due to local forcing. A striking feature of the initial bias development is that it is accompanied by an immediate (during the first day) southward shift of the ABFZ in all performed experiments (Fig. 3), including TAU-SE in which the prescribed wind stress from ERA-Interim in the SETA region is stronger in February-March than the modeled wind stress. This could be due to local errors in wind stress patterns over Cape Frio $\left(17^{\circ} \mathrm{S}\right)$.

Two characteristics of wind field errors have been shown by previous studies to be of importance: the location of the wind maximum off Cape Frio and the wind stress curl. The first error is typical for both, climate models and atmospheric reanalysis products. Whereas coarse resolution model products (with horizontal resolution of more than $1.5^{\circ}$ ) are not at all able to simulate the wind maximum off Cape Frio (Machu et al. 2015; Patricola and Chang 2016), model products with horizontal resolutions of less than $1^{\circ}$, in particular our HR model and the ERA-Interim reanalysis, simulate this maximum generally slightly shifted to the south with respect to the satellite data [Fig. 13 in the present study and Fig. 3 in Patricola and Chang (2016)]. The latter should lead to a reduced northward extent of the Benguela current and therefore to a southward shift of the ABFZ. Deficiencies in simulating the local wind stress curl over ABFZ has been shown to be a major factor controlling its position through its impact on the southward extent of the Angola current (Koseki et al. 2017; Colberg and Reason 2006).

The sensitivity experiments of Small et al. (2015) to improving coastal winds in the Benguela region in a highresolution regional model (coupled to the CCSM4 CGCM) led to a $2-3{ }^{\circ} \mathrm{C}$ cooling of SST. This suggests that prescribing a realistic wind stress forcing in the Benguela system may eliminate at least a part of the bias that remains in TAUEQ after correcting the equatorial errors. In order to quantify the impact of realistic wind stress and in particular to assess the respective role of the position/strength of the wind maximum off Cape Frio and wind stress curl, additional sensitivity experiments are required. Due to computational and time constraints, they could not be performed in the framework of the present study, where the main focus was on the role of the bias of equatorial origin.

\subsection{Role of atmospheric physics}

Along with the local dynamical forcing, the errors in the local heat fluxes may also contribute to the initial formation of the SETA warm SST bias. Figure 15 demonstrates that during the first approximately 10 days (20 days) the net heat flux is overestimated in ABA in CTRL-HR (CTRL-LR) with respect to the reference products, due to an excessive solar radiation. This reflects the well-known problem of climate models that underestimate the low-level stratocumulus clouds over the eastern subtropical oceans. Further evolution of the net heat flux error shows that the ocean is rapidly reacting to excessive solar radiation and increasing SST through enhanced longwave cooling and turbulent heat loss, and that from the beginning of April, the latent cooling alone largely overcompensates the shortwave warming in terms of impact on net surface flux. Although the latter confirms the results of our study indicating that the excessive solar flux is not the only and/or dominant factor explaining the growing SST bias, still it should contribute to the warm SST error. Voldoire et al. (2013) showed that correcting the solar flux over the South-Eastern Atlantic in the LR version of the CNRM model leads to a local reduction of the SST bias by $1-2{ }^{\circ} \mathrm{C}$, and also to a significant reduction (up to $1.5^{\circ} \mathrm{C}$ ) of the cold tongue bias. The LR and HR model share exactly the same error in shortwave flux in the ABA region (Fig. 15a, b) associated with a very similar initial error in SST (Fig. 6 (middle)). Thus, if we assume that the SST bias is the result of a linear superposition of the partial fluxes biases, one would expect that the error in solar radiation may explain about half of the initial (observed during first month and reaching about $1.8^{\circ} \mathrm{C}$ ) SETA warm SST bias in the HR model.

On the other hand, Voldoire et al (2014) report an unrealistic SST-low cloud feedback in the LR model showing that improving the SETA SST even worsens the cloud cover. Since the HR model uses the same atmospheric physical parametrisations and the same atmospheric vertical resolution as the LR model, it is not surprising that the low level clouds in the HR model also exhibit a weak sensitivity to the underlying SST. Indeed, Fig. 15c shows that despite a significant reduction of the SETA SST bias in the TAU-EQ experiment, the local errors in shortwave and longwave radiative fluxes in ABA remain exactly the same as in CTRL-HR, and are very similar to CTRL-LR. Similarly, in SBEN the radiative fluxes are not sensitive to change in SST between CTRLHR and TAU-EQ, although the net radiative surface flux is 

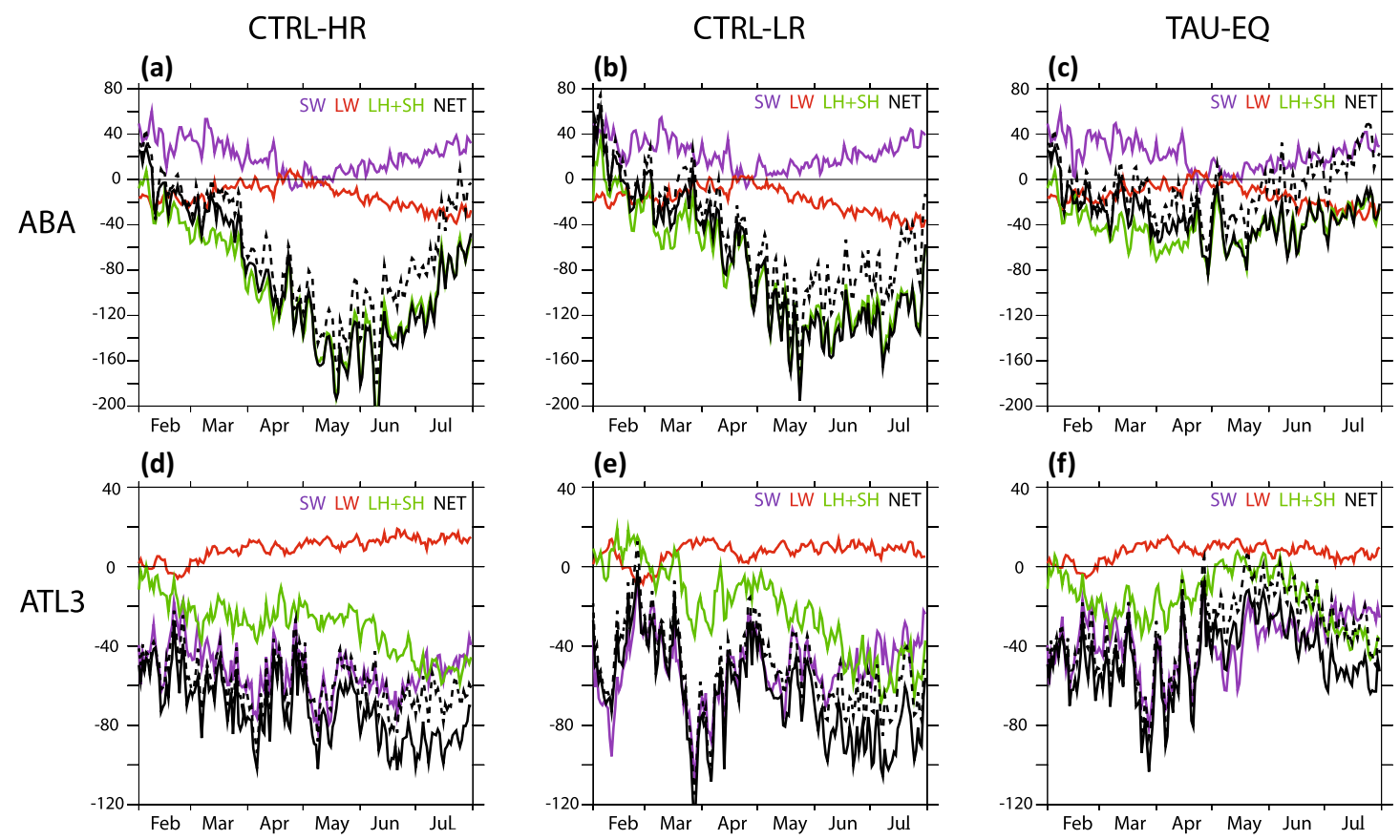

Fig. 15 Evolution of daily-mean error in surface heat fluxes averaged over (top) ABA and (bottom) ATL3 boxes with respect to OAflux (Praveen Kumar et al. 2012) in (left) CTRL-HR, (middle) CTRL-LR and (right) TAU-EQ. Purple—net shortwave, red—net longwave flux,

on average slightly weaker in CTRL-HR than in CTRL-LR (not shown).

Interestingly, in ATL3 there is a response of clouds to the SST cooling in TAU-EQ with respect to CTRL-HR. In this region the shortwave radiation is strongly underestimated in both control hindcasts suggesting an enhanced cloud cover (Fig. 15d, e). A cooler SST in TAU-EQ with respect to CTRL-HR, especially in June-July, suppresses the convection (not shown) and reduces the associated cloud cover, which leads to an increasing total shortwave flux (Fig. 15f). However, even in TAU-EQ the cloud cover and precipitation are still overestimated in ATL3 and exhibit unrealistic patterns over the Tropical Atlantic with underestimated precipitation in the west and excessive precipitations in the east (not shown). This bias in precipitation reflects deficiencies in simulating tropical convection, which has been suggested by several studies as a main cause of the Atlantic equatorial westerly wind bias (Richter et al. 2012 ; Zuidema et al. 2016; Siongco et al. 2017).

Accordingly, in CNRM-CM5 the deficiency seems to be associated with convection errors in the western equatorial Atlantic that impact the pressure gradient over the Equator through convective heating (R. Roehrig, personal communication). In the coming new version of CNRMCM, designed for CMIP6, preliminary results show a significant improvement of the Tropical Atlantic convection, and by consequence equatorial surface easterlies. Note green-turbulent latent and sensible heat, black-total net heat flux. The dashed black line indicates the error in total net heat flux with respect to TropFlux (Yu et al. 2008). Positive heat fluxes correspond to ocean heat gain. Unit: $\mathrm{W} / \mathrm{m}^{2}$

that CNRM-CM6 uses an increased vertical resolution in the atmosphere (91 levels), which also provides potential for improving the equatorial and SETA atmospheric biases (Harlass et al. 2017).

\section{Concluding remarks}

The development of the Eastern Tropical Atlantic SST bias in a HR version of the CNRM climate model was investigated based on full-field initialized seasonal hindcasts starting at 1 February of each year for the period 2000-2009. In the near coastal SETA region (ABA) the bias starts to develop from the first days of the hindcast, reaches its maximum of about $5.3{ }^{\circ} \mathrm{C}$ in April-May and then slowly decays down to $3{ }^{\circ} \mathrm{C}$ in July. In the eastern equatorial Atlantic (ATL3) the error is rather weak (less than $1{ }^{\circ} \mathrm{C}$ ) until the end of May but then it suddenly increases up to $2.4{ }^{\circ} \mathrm{C}$ (on average in June-July) reflecting the poor simulation of the seasonal development of the Atlantic cold tongue by the model. The SST biases in SETA and ATL3 are linked and can be explained, to a large extent, by the westerly wind bias at the equator resulting in an erroneous oceanic mean state. In particular, the TAU-EQ experiment, in which the modeled wind stress in the equatorial Atlantic $\left(5^{\circ} \mathrm{S}-5^{\circ} \mathrm{N}\right)$ is replaced with ERA-Interim wind stress, indicates that in the HR model the equatorial wind errors contribute about half 
to the SST warm biases: It explains 57\% of the total SST bias in ABA in March-May and 48\% of the total SST bias in ATL3 in June-July. A mixed layer heat budget analysis demonstrates that the remote equatorial forcing of the SST bias in ABA is associated with an anomalous warm horizontal advection. The latter seems to be associated with propagation of equatorial intraseasonal Kelvin waves that reaching the coast propagate too far south due to the erroneous ocean mean state.

Comparison with the LR version of the CNRM-CM demonstrates that increasing the resolution does not allow improving significantly the SST in the Equatorial Atlantic and SETA regions and that, in general, similar processes are responsible for the SST biases in the HR and LR versions. This confirms, to a great extent, conclusions of previous studies suggesting that the higher resolution is unlikely a simple solution to the SETA bias issue (e.g. Doi et al. 2012; Patricola et al. 2012; Zuidema et al. 2016). However, a strong reduction of the biases in the HR version with respect to the LR version is observed in our model locally in the near-coastal Southern Benguela region (SBEN) and is due to a better representation of fine-scale atmospheric and oceanic processes controlling the coastal upwelling. In the northern Benguela upwelling region (ABA), from February to May the SST errors in LR and HR evolve generally in a similar way, because the upwelling is suppressed by the warm advection from the equator. We expect however that once the equatorial errors are corrected, the difference in SST between LR and HR in March-May in ABA would be of the same order as the corresponding difference in SBEN.

A negative feedback process occurs in the HR model in the Benguela region in June-July and results in an apparent seasonal weakening of the SST bias. A strong SST bias developing in the Eastern Tropical Atlantic in June-July is accompanied by the development of a low-level convergence zone and associated intensification of the surface wind along the southeastern coast of Africa, especially over the Angola current region and northern Benguela system (Fig. 1e, f). The surface wind intensification in turn leads to a stronger local heat loss through latent heat flux but also, and more importantly, through enhanced upwelling. Note that a similar negative feedback process is observed during interannual warm events in the Eastern Tropical Atlantic ( $\mathrm{Hu}$ and Huang 2007). In the TAU-SE experiment that uses the ERAInterim wind in SETA, the bias almost does not weaken in June-July, because the ERA-Interim wind stress is about $20.4 \%$ weaker (on average over ABA) than the HR model wind stress. On the other hand, in the LR model, despite the fact that the alongshore winds intensify in June-July (not shown) similarly to CTRL-HR, this intensification has a much smaller impact on the SST with respect to the HR model since the coastal upwelling is not resolved in the LR model. By consequence, over the Benguela upwelling region, the SST bias appears to be less season-dependent in the LR model than in the HR model. Overall, the results of the inter-comparison of the SETA SST bias evolution in the different hindcast experiments performed in this study can be interpreted in terms of the relative contributions of the cold horizontal advection associated with local offshore Ekman transport and (erroneous) warm horizontal advection associated with equatorial forcing.

Finally, the results of our study emphasize the limitations of the methodology of fixing a parameter of the climate system to realistic values in order to evaluate (in a linear way) its contribution to the fully-coupled errors. A heat flux analysis of the simulation with improved SST (TAU-EQ) suggests that a linear superposition of partial fixes may not result in fixing the full system bias and that improving the climate models requires considering the bias issue as a problem in which dynamics, physics, and non-linear feedbacks are simultaneously involved.

Acknowledgements Eric Maisonnave, Sophie Valcke and Marie-Pierre Moine are gratefully thanked for their advice and guidance in performing the simulations with the HR version of the CNRM model. Prof. Mechoso and two anonymous reviewers are thanked for their comments, which improved the manuscript. The authors acknowledge the GLORYS project for providing the ocean reanalysis data. GLORYS is jointly run by the MERCATOR-OCEAN, CORIOLIS and CNRS/ INSU. ERA-Interim data provided courtesy ECMWF. QuikSCAT wind stress was obtained from CERSAT/IFREMER. The heat flux products used are from the (1) WHOI OAFlux project (http://oaflux.whoi.edu) funded by the NOAA Climate Observations and Monitoring (COM) program and (2) TropFlux project produced under a collaboration between LOCEAN/IPSL (France) and NIO/CSIR (India) and supported by IRD (France). This study was supported by the EU FP7/2007-2013 PREFACE Project (Grant 603521). KG was also supported by Fondecyt (Grant 1171861).

Open Access This article is distributed under the terms of the Creative Commons Attribution 4.0 International License (http://creativeco mmons.org/licenses/by/4.0/), which permits unrestricted use, distribution, and reproduction in any medium, provided you give appropriate credit to the original author(s) and the source, provide a link to the Creative Commons license, and indicate if changes were made.

\section{References}

Astudillo O, Dewitte B, Mallet M, Frappart F, Rutllant JA, Ramos M, Bravo L, Goubanova K, Illig S (2017) Surface winds off PeruChile: observing closer to the coast from radar altimetry. Remote Sens Environ 191:179-196

Bachèlery M-L, Illig S, Dadou I (2015) Interannual variability in the South-East Atlantic Ocean, focusing on the Benguela upwelling system: remote versus local forcing. J Geophys Res Oceans. https ://doi.org/10.1002/2015JC011168

Belamari S (2005) Report on uncertainty estimates of an optimal bulk formulation for surface turbulent fluxes. Marine EnviRonment and Security for the European Area-Integrated Project (MERSEA IP), Deliverable D4.1.2, p 29 
Benestad RE, Sutton RT, Anderson DLT (2002) The effect of El Niño on intraseasonal Kelvin waves. Quart J Roy Meteor Soc 128:1277-1291

Cabos W, Sein, DV, Pinto JG et al (2017) The South Atlantic anticyclone as a key player for the representation of the tropical Atlantic climate in coupled climate models. Clim Dyn 48(11-12):4051-4069

Cambon G, Goubanova K, Marchesiello P, Dewitte B, Illig S (2013) Assessing the impact of downscaled winds on a regional ocean model simulation of the Humboldt system. Ocean Model 65:11-24

Colberg F, Reason CJC (2006) A model study of the Angola Benguela frontal zone: sensitivity to atmospheric forcing. Geophys Res Lett 33(19). https://doi.org/10.1029/2006GL027463

Davey M, Coauthors (2002) STOIC: a study of coupled model climatology and variability in tropical ocean regions. Clim Dyn 18:403-420

Dee DP, Uppala SM, Simmons AJ, Berrisford P, Poli P, Kobayashi S, Andrae U, Balmaseda MA, Balsamo G, Bauer P, Bechtold P, Beljaars ACM, van de Berg L, Bidlot J, Bormann N, Delsol C, Dragani R, Fuentes M, Geer AJ, Haimberger L, Healy SB, Hersbach H, Hólm EV, Isaksen L, Kållberg P, Köhler M, Matricardi M, McNally AP, Monge-Sanz BM, Morcrette J-J, Park B-K, Peubey C, de Rosnay P, Tavolato C, Thépaut J-N, Vitart F (2011) The ERA-interim reanalysis: configuration and performance of the data assimilation system. QJR Meteorol Soc 137:553-597. https ://doi.org/10.1002/qj.828

Déqué M, Dreveton C, Braun A, Cariolle D (1994) The ARPEGEIFS atmosphere model: a contribution to the French community climate modelling. Clim Dyn 10:249-266

Doi T, Vecchi GA, Rosati AJ, Delworth TL (2012) Biases in the Atlantic ITCZ in seasonal-interannual variations for a coarse and a high resolution coupled climate model. J Clim 25:5494-5511.https:// doi.org/10.1175/JCLI-D-11-00360.1

Ferry N et al (2010) Mercator global eddy permitting ocean reanalysis GLORYS1V1: description and results. Mercator Ocean Q Newslett 36:15-27

Florenchie P, Reason CJC, Lutjeharms JRE, Rouault M (2004) Evolution of interannual warm and cold events in the southeast Atlantic Ocean. J Clim 17:2318-2334

Giese BS, Carton JA (1994) The seasonal cycle in a coupled oceanatmosphere model. J Clim 7:1208-1217

Giordani H, Caniaux G, Voldoire A (2013) Intraseasonal mixed layer heat budget in the equatorial Atlantic during the cold tongue development in 2006. J Geophys Res Oceans 118:1-22. https:// doi.org/10.1029/2012JC008280

Goubanova K, Illig S, Machu E, Garçon V, Dewitte B (2013) SST subseasonal variability in the central Benguela upwelling system as inferred from satellite observations (1999-2009). J Geophys Res Oceans 118:4092-4110

Grodsky SA, Carton JA, Nigam S, Okumura YM (2012) Tropical Atlantic biases in CCSM4. J Clim 25:3684-3701. https://doi. org/10.1175/JCLI-D-11-00315.1

Guemas V, Chevallier M, Déqué M, Bellprat O, Doblas-Reyes F (2016) Impact of sea ice initialisation on sea ice and atmosphere prediction skill on seasonal timescales. Geophys Res Lett 43(8):3889-3896

Haarsma RJ et al (2016) High resolution model intercomparison project (HighResMIP). Geosci Model Dev 9:4185-4208. https://doi. org/10.5194/gmd-9-4185-2016

Harlass J, Latif M, Park W (2017) Alleviating tropical Atlantic sector biases in the Kiel climate model by enhancing horizontal and vertical atmosphere model resolution: climatology and interannual variability. Clim Dyn. https://doi.org/10.1007/s00382-017-3760-4

Hourdin F, Găinusă-Bogdan A, Braconnot P, Dufresne J-L, Traoree A-K, Rio C (2015) Air moisture control on ocean surface temperature, hidden key to the warm bias enigma. Geophys Res Lett 42(24):10,885-10,893

Hu Z-Z, Huang B (2007) Physical processes associated with the tropical Atlantic SST gradient during the anomalous evolution in the Southeastern Ocean. J Clim 20(14):3366-3378

Huang B, Hu Z-Z, Jha B (2007) Evolution of model systematic errors in the tropical Atlantic basin from coupled climate hindcasts. Clim Dyn 28:661-682. https://doi.org/10.1007/s00382-006-0223-8

Hummels R, Dengler M, Brandt P, Schlundt M (2014) Diapycnal heat flux and mixed layer heat budget within the Atlantic cold tongue. Clim Dyn 43(11):3179-3199

Illig S, Dewitte B, Ayoub N, du Penhoat Y, Reverdin G, De Mey P, Bonjean F, Lagerloef GSE (2004) Interannual long equatorial waves in the tropical Atlantic from a high-resolution ocean general circulation model experiment in 1981-2000. J Geophys Res 109(C2). https://doi.org/10.1029/2003JC001771

Imbol Koungue RA, Illig S, Rouault M (2017), Role of interannual Kelvin wave propagations in the equatorial Atlantic on the Angola Benguela Current system. J Geophys Res Oceans. https://doi. org/10.1002/2016JC012463

Jouanno J, Marin F, du Penhoat Y, Sheinbaum J, Molines JM (2011) Seasonal heat balance in the upper $100 \mathrm{~m}$ of the equatorial Atlantic Ocean. J Geophys Res 116:C09003. https://doi. org/10.1029/2010JC006912

Koseki S, Keenlyside N, Demissie T, Toniazzo T, Counillon F, Bethke I, Ilicak M, Shen M-L (2017) Causes of the large warm bias in the Angola-Benguela frontal zone in the Norwegian earth system model. Clim Dyn. https://doi.org/10.1007/s00382-017-3896-2

Louis J-F (1979) A parametric model of vertical eddy fluxes in the atmosphere. Bound Layer Meteorol 17:187-202

Lubbecke JF, Boning CW, Keenlyside NS, Xie SP (2010) On the connection between Benguela and equatorial Atlantic Niños and the role of the south Atlantic anticyclone. J Geophys Res 115:C09015. https://doi.org/10.1029/2009JC005964

Lütjeharms JER, Meeuwis JM (1987) The extent and variability of south-east Atlantic upwelling. In: Payne ALL, Gulland JA, Brink KH (eds) The Benguela and comparable ecosystems, S Afr J Mar Sci vol 5, pp 51-62

Ma C-C, Mechoso CR, Robertson AW, Arakawa A (1996) Peruvian stratus clouds and the tropical Pacific circulation: a coupled ocean-atmosphere GCM study. J Clim 9:1635-1645. https://doi. org/10.1175/1520-0442(1996)009,1635:PSCATT.2.0.CO;2

Machu E, Goubanova K, Le Vu B, Gutknecht E, Garcon V (2015) Downscaling biogeochemistry in the Benguela eastern boundary current. Ocean Model 90:57-71. https://doi.org/10.1016/j.ocemo d.2015.01.003

Madec G (2008) NEMO ocean engine. Note du Pole de modélisation. Institut Pierre-Simon Laplace (IPSL), France, No. 27, ISSN No. 1288-1619

Marchesiello P, Estrade P (2010) Upwelling limitation by onshore geostrophic flow. J Mar Res 68:37-62. https://doi.org/10.1357/00222 4010793079004

Milinski S, Bader J, Haak H, Siongco AC, Jungclaus JH (2016) High atmospheric horizontal resolution eliminates the wind-driven coastal warm bias in the southeastern tropical Atlantic. Geophys Res Lett 43(19):10455-10462

Monerie PA, Coquart L, Maisonnave E, Moine MP, Terray L, Valcke $S$ et al (2017) Decadal prediction skill using a high-resolution climate model. Clim Dyn. https://doi.org/10.1007/s0038 2-017-3528-x

Noilhan J, Planton S (1989) A simple parameterization of land surface processes for meteorological models. Mon Weather Rev 117:536-549

Oki T, Sud YC (1998) Design of total runoff integrating pathways (TRIP). A global river channel network. Earth Interact 2:1-36 
Ortega P, Guilyardi E, Swingedouw D, Mignot J, Nguyen S (2017) Reconstructing extreme AMOC events through nudging of the ocean surface: a perfect model approach. Clim Dyn. https://doi. org/10.1007/s00382-017-3521-4 (ISSN 0930-7575)

Patricola C, Chang P (2016) Structure and dynamics of the Benguela low-level coastal jet. Clim Dyn. https://doi.org/10.1007/s0038 2-016-3479-7

Patricola CM, Li M, Xu Z et al (2012) An investigation of tropical Atlantic bias in a high-resolution coupled regional climate model. Clim Dyn 39(9-10):2443-2463. https://doi.org/10.1007/s0038 2-012-1320-5

Peter C, Hénaff ML, du Penhoat Y, Menkès C, Marin F, Vialard J, Caniaux G, Lazar A (2006), A model study of the seasonal mixed-layer heat budget in the equatorial Atlantic. J Geophys Res 111:C06014. https://doi.org/10.1029/2005JC003157

Planton Y, Voldoire A, Giordani H, Caniaux G (2018) Main processes of the Atlantic cold tongue interannual variability. Clim Dyn 50(5-6):1495-1512

Polo I, Lazar A, Rodriguez-Fonseca B, Arnault S (2008) Oceanic Kelvin waves and tropical Atlantic intraseasonal variability: 1. Kelvin wave characterization. J Geophys Res 113:C07009

Praveen Kumar B, Vialard J, Lengaigne M et al (2012) TropFlux: airsea fluxes for the global tropical oceans-description and evaluation. Clim Dyn 38:1521

Reynolds RW, Rayner NA, Smith TM, Stokes DC, Wang W (2002) An improved in situ and satellite SST analysis for climate. J Clim 15:1609-1625

Richter I (2015) Climate model biases in the eastern tropical oceans: causes, impacts and ways forward. WIR Clim Change 6(3):345358. https://doi.org/10.1002/wcc.338

Richter I, Mechoso CR (2006) Orographic influences on the subtropical stratocumulus. J Atmos Sci 63:2585-2601

Richter I, Xie S-P, Wittenberg AT, Masumoto Y (2012) Tropical Atlantic biases and their relation to surface wind stress and terrestrial precipitation. Clim Dyn 38:985-1001. https://doi.org/10.1007/ s00382-011-1038-9

Salas-Mélia D (2002) A global coupled sea ice-ocean model. Ocean Model 4:137-172

Schlundt M, Brandt P, Dengler M, Hummels R, Fischer T, Bumke K, Krahmann G, Karstensen J (2014) Mixed layer heat and salinity budgets during the onset of the 2011 Atlantic cold tongue. J Geophys Res: Oceans 119(11):7882-7910

Seiki A, Takayabu YN (2007) Westerly wind bursts and their relationship with intraseasonal variability and ENSO. Part I: statistics. Mon Weather Rev 135:3325-3345

Shannon LV, Agenbag JJ, Buys MEL (1987) Large and meso-scale features of the Angola-Benguela front. S Afr J Mar Sci 5:11-34

Shonk JK, Guilyardi E, Toniazzo T, Woolnough S, Stockdale T (2016) Identifying causes of Western Pacific ITCZ drift in ECMWF system 4 hindcasts. Clim Dyn. https://doi.org/10.1007/s0038 2-017-3650-9

Siongco AC, Hohenegger C, Stevens B (2017) Sensitivity of the summertime tropical Atlantic precipitation distribution to convective parameterization and model resolution in ECHAM6. J Geophys Res Atmos 122:2579-2594. https://doi.org/10.1002/2016JD0260 93

Small RJ, Curchitser E, Hedstrom K, Kauffman B, Large W (2015) The Benguela upwelling system: quantifying the sensitivity to resolution and coastal wind representation in a global climate model. J Clim 28:9409-9432. https://doi.org/10.1175/ JCLI-D-15-0192.1

Stockdale T, Latif M, Burgers G, Wolff J-O (1994) Some sensitivities of a coupled ocean-atmosphere GCM. Tellus 46A:367-380

Swingedouw D, Mignot J, Labetoulle S, Guilyardi E, Madec G (2013) Initialisation and predictability of the AMOC over the last 50 years in a climate model. Clim Dyn 40:2381-2399

Taylor KE, Stouffer RJ, Meehl GA (2012) An overview of CMIP5 and the experiment design. Bull Am Meteorol Soc 93:485-498. https ://doi.org/10.1175/BAMS-D-11-00094

Toniazzo T, Woolnough S (2014) Development of warm SST errors in the southern tropical Atlantic decadal hindcasts. Clim Dyn 43:2889-2913. https://doi.org/10.1007/s00382-013-1691-2

Valcke S (2013) The OASIS3 coupler: a European climate modelling community software. Geosci Model Dev 6:373-388

Valcke S, Craig T, Coquart L (2013) OASIS3-MCT user guide, OASIS3-MCT 2.0 technical report, TR/CMGC/13/17, CERFACS/ CNRS SUC URA No 1875, Toulouse, pp 54

Vancoppenolle M, Fichefet T, Goosse H, Bouillon S, Madec G, Maqueda MAM (2009) Simulating the mass balance and salinity of Arctic and Antarctic sea ice. 1. Model description and validation. Ocean Model 27:33-35

Veitch JA, Florenchie P, Shillington FA (2006) Seasonal and interannual fluctuations of the Angola-Benguela frontal zone (ABFZ) using $4.5 \mathrm{~km}$ resolution satellite imagery from 1982 to 1999 . Int J Remote Sens 27:987-998. https://doi.org/10.1080/0143116050 0127914

Veitch J, Penven P, Shillington F (2009) The Benguela: a laboratory for comparative modeling studies. Prog Oceanogr 83:296-302. https ://doi.org/10.1016/j.pocean.2009.07.008

Voldoire A et al (2013) The CNRM-CM5. 1 global climate model: description and basic evaluation. Clim Dyn 40:2091-2121

Voldoire A, Claudon M, Caniaux G, Giordani H, Roehrig R (2014) Are atmospheric biases responsible for tropical Atlantic SST biases in the CNRM-CM5 model? Clim Dyn 43:2963-2984, https://doi. org/10.1007/s00382-013-2036-x

Wahl S, Latif M, Park W, Keenlyside N (2011) On the tropical Atlantic SST warm bias in the Kiel climate model. Clim Dyn 36:891-906. https://doi.org/10.1007/s00382-009-0690-9

Xu Z, Chang P, Richter I, Kim W, Tang G (2014a) Diagnosing southeast tropical Atlantic SST and ocean circulation biases in the CMIP5 ensemble. Clim Dyn 43:3123-3145. https://doi. org/10.1007/s00382-014-2247-9

Xu Z, Li M, Patricola CM, Chang P (2014b) Oceanic origin of southeast tropical Atlantic biases. Clim Dyn 43:2915-2930. https://doi. org/10.1007/s00382-013-1901-y

Yu L, Jin X, Weller RA (2008) Multidecade global flux datasets from the objectively analyzed air-sea fluxes (OAFlux) project: latent and sensible heat fluxes, ocean evaporation, and related surface meteorological variables. OAFlux project technical report. OA-2008-01. Woods Hole Oceanographic Institution, Woods Hole, pp 64

Zuidema $\mathrm{P}$ et al (2016) Challenges and prospects for reducing coupled climate model SST biases in the eastern tropical Atlantic and Pacific oceans: the US CLIVAR Eastern Tropical Oceans synthesis working group. BAMS. https://doi.org/10.1175/BAMSD-15-00274.1 